\title{
Quaternary loess-paleosol sequences in East and Central Asia in comparison with Central Europe - micromorphological and paleoclimatological conclusions
}

\author{
Arnt Bronger, Libuše Smolíková
}

\section{Arnt Bronger}

do3lkp@t-online.de

Department of Geography, University of Kiel, D-24098 Kiel, Germany.

Libuše Smolíková

Faculty of Science, Charles University, Albertov 6, 12000 Prague, Czech Republic

BOL. SOC. GEOL. MEX. 2019

VOL. 71 NO. 1

P. $65-92$

http://dx.doi.org/10.18268/BSGM2019v7 lnla5

Manuscript received: May 5, 2017.

Corrected manuscript received: December 12, 2017.

Manuscript accepted: January 15, 2018.

\section{ABSTRACT}

Detailed knowledge of the genesis of paleosols is needed to establish loess-paleosol stratigraphies that can be used for paleoclimatic reconstruction. Most paleosols, however, are truncated and largely recalcified from overlying loess. Micromorphological studies allow e.g. primary and secondary carbonates to be distinguished and provide unequivocal evidence of clay illuviation. This enables the recognition of typical loess, weathered loess and the recognition of different genetic soil horizons, such as $\mathrm{CB}, \mathrm{BC}, \mathrm{Ah}, \mathrm{Bw}$ and $\mathrm{Bt}$ horizons. For the Brunhes epoch, the sequence at Karamaydan, Tadjikitan, is more detailed than the corresponding section in Luochuan, China and even more than in the Carpathian Basin except for the last glaciation, however, similar to the pedocomplexes of the composite section in Czechia. The very good correlation with the deep-sea oxygen isotope record, which includes the development of an accurate astronomical time scale, allows a detailed chronostratigraphical subdivision of the loess-paleosol sequence in Karamaydan down to the substage level, which therefore should be regarded as a key sequence in the temperate climatic belt of the Northern Hemisphere for reconstructing the climate history of the Brunhes epoch. An example of the incompleteness of the loess-paleosol sequence in the Carpathian Basin is the very strongly developed F6 paleosol, a rubefied earthy Braunlehm (-Lessivé) in the sense of Kubiena in Stari Slankamen (Serbia) with a distinct Ckm horizon. This soil was earlier (1976) thought to be a soil of the "subtropical

\section{RESUMEN}

El conocimiento detallado de la génesis de los paleosuelos es necesario para establecer la estratigrafia de loess-paleosuelos, que se pueden utilizar para la reconstrucción paleoclimática. La mayoría de los paleosuelos, sin embargo, están truncados y en gran parte recalcificados por el loess que le sobreyace. Los estudios micro morfológicos permiten distinguir, por ejemplo, los carbonatos primarios y de los secundarios y proporcionar evidencia inequívoca de la iluviación de la arcilla. Esto permite el reconocimiento del loess típico, del loess intemperizado $y$ el reconocimiento de diferentes horizontes genéticos del suelo, tales como horizontes $C B$, BC, Ah, Bw y Bt. Para la época Brunhes, la secuencia en Karamaydan, Tadjikistan, es más detallada que la correspondiente en Luochuan, China e incluso más que en la Cuenca de los Cárpatos, excepto para las últimas glaciaciones. Sin embargo, es similar a los pedocomplejos de la sección compuesta en República Checa. La buena correlación con el registro de isótopos de oxígeno en aguas profundas que incluye el desarrollo de una escala de tiempo astronómica precisa, permite una subdivisión cronoestratigráfica detallada de la secuencia de loess-paleosuelo en Karamaydan hasta el nivel de subetapa, por lo tanto debe considerarse como una secuencia clave en el cinturón climático templado del hemisferio norte, en la reconstrucción de la historia climática de la época Brunhes. Un ejemplo de la fragmentación de la secuencia loess-paleosuelo en la cuenca de los Cárpatos es la presencia del paleosuelo muy desarrollado, F6, un Braunlehm terroso rubificado (lessivé), en el sentido de Kubiena en Stari Slankamen (Serbia), que tiene un horizonte Ckm distintivo. Este suelo era considerado anteriormente (1976) un suelo de la "provincia de suelo subtropical " según Kubiena. Posteriormente, el suelo F6 se 
soil province" according to Kubiena. Later the F6 soil was correlated with the three soils of the S5 pedocomplex in Luochuan (1989) and therefore with the 5-6 soils in the two pedocomplexes PKVI and PKV at Karmaydan (1998), which were formed over a period of about $140 \mathrm{ka}$, although pedogenesis was interrupted several times by loess deposition. The F6 soil is therefore an example of a welded or multistory paleosol. Loess paleosol sequences of the early Würm period in the Central Asian Kashmir Basin are well comparable with those in Central Europe. For most of the Matuyama epoch, the central and lower parts of the sequence at Chashmanigar/Tadjikistan show more pronounced paleosols (about twenty) than the equivalent parts at Luochuan. In the Carpatian Basin only at Stari Slankamen are three strongly developed though truncated rubefied braunlehms (F9-F11) above Neogene sediments. In Lower Austria, however, many paleosols, mostly classified as Braunlehms, rubefied Braunlehms and Rotlehms, are exposed, especially in Stranzendorf and Krems-shooting range. Mineralogical investigations of the silt and clay subfractions show that there is little difference in the type and amount of pedogenic clay mineral formation between the Holocene soils and the paleosols of the Brunhes epoch at Karamaydan and of the Matuyama epoch at Chashmanigar. This suggests that the interglacial climates represented by the $\mathrm{B}$ or Bt horizons of the buried paleosols of late, middle, and early Pleistocene age were roughly similar to that of the Holocene. Therefore the partly rubefied Braunlehms of middle and early Pleistocene age in the Carpathian Basin and in Lower Austria must be regarded as multistory paleosols.

\section{Keywords: loess-paleosol sequences, multistory paleosols, paleoclimate.}

correlacionó con los tres suelos del pedocomplejo S5 en Luochuan (1989) y por lo tanto con los 5-6 suelos en los dos pedocomplejos PKVI y PKV en Karmaydan (1998), que se formaron durante un periodo de aproximadamente $140 \mathrm{ka}$ a pesar de que la pedogénesis fue interrumpida varias veces por la depositación de loess. El suelo F6 es, por lo tanto, un ejemplo de un paleosuelo soldado o de varios ciclos. Las secuencias loess-paleosuelos del período Würm temprano en Asia Central son comparables con las de Europa Central. Durante la mayor parte de la época Matuyama, las partes central e inferior de la secuencia en Chashmanigar, Tadjikistan muestran paleosuelos más pronunciados (aproximadamente veinte) que las partes equivalentes en Luochuan. En la cuenca de los Cárpatos, solamente en Stari Slankamen son tres Braunlehms rubificados (F9-F11), truncados, fuertemente desarrollados, sobre los sedimentos neógenos. En Baja Austria, sin embargo, muchos paleosuelos, en su mayoría clasificados como Braunlehms, Braunlehms rubificados y Rotlehms, están expuestos, especialmente en Stranzendorf y en Krems. Las investigaciones mineralógicas de las subfracciones de limo y arcilla demuestran que hay poca diferencia en el tipo y cantidad de minerales arcillosos de formación pedogénica entre los suelos del Holoceno y los paleosuelos de la época de Brunhes en Karamaydan y de la época de Matuyama en Chashmanigar. Esto sugiere que los climas interglaciares representados por los horizontes $B$ o Bt de los paleosuelos sepultados del Pleistoceno tardío, medio y temprano eran aproximadamente similares a los del Holoceno. Por lo tanto, los Braunlehms rubificados del Pleistoceno en la cuenca de los Cárpatos y en Austria Baja deben ser considerados como paleosuelos de varios ciclos.

Palabras clave: secuencias loess-paleosuelos, paleosuelo multinivel, paleoclima. 


\section{Introduction}

Recent small climatic fluctuations on a $100-1000$ year time scale can be correlated at least throughout the temperate climatic belt of the Northern Hemisphere, e.g. the Little Ice Age with a decline of the mean annual temperature of $<1^{\circ} \mathrm{C}$ from 1850 to 1950 (Maisch, 1995). This suggests that major climatic changes on a 100000 year scale (glacial- interglacial cycles) and also on a 10000 year scale (the approximate length of an interglacial), must be of similar ages throughout the temperate climatic belt of the Northern Hemisphere. This concept allows continental pedostratigraphical correlations.

The second necessity for a reliable pedostratigraphy is a time frame of the formations of the loess-paleosol sequences (LPS). This is given first by the knowledge of the position of the Brunhes/ Matuyama $(\mathrm{B} / \mathrm{M})$ boundary in the LPS in Luochuan/China, Karamaydan and Chashmanigar/ Tadjikistan and various LPS in Central Europe. Second, the chronostatigraphical position of the last interglacial soil in all LPS is known by thermoluminescence dates (see chapter 3). Third, appropriate methods are necessary for a paleoclimatic interpretation of paleosols. These issues are still controversial and intensively discussed until recently, therefore a methodological chapter is needed.

\section{Methodology}

For paleoclimatic deductions from LPS it is necessary to understand the processes involved in the genesis of paleosols. This is, however, often difficult because most of the buried paleosols are truncated and more or less recalcified from the overlying loess. Micromorphology allows primary and secondary carbonates to be distinguished; examples are given in Figures 1a and 1c (see also photos 1, 8-12, 17-19 and 23 in Bronger, 1976). This genetic distinction is especially important, for example it allows the distinction between Degraded Chernozems, now referred to as Phaeozems in the World Reference Base (IUSS, 2014) and Chernozems still containing primary carbonates in the lower part of the profile. The development of Phaeozems needs a moister climate (udic soil moisture regime) than Chernozems sensu stricto, which develop in an ustic soil moisture regime (Bronger, 1991, 2003b; for definitions see esp. diagrams 3, 6, 7, 9, 11, 13, and 14 in Soil Survey Staff, 1999).

Micromorphology especially provides a complete view of soil development through different stages, even in polygenetic pedocomplexes (e.g. Kubiena, 1959, 1964; Smolíková, 1967, 1971, 1990; Bronger, 1970, 1976; Catt, 1990; Smolíková et al., 2010) and often reveals the effects of diagenetic processes after burial. Micromorphology also provides an unequivocal indication of clay illuviation. This process occurs in the $\mathrm{pH}$ range $4.5-6$ (in $0.1 \mathrm{M} \mathrm{KCl}$ or $\mathrm{CaCl}_{2}$ ) in soils on plateau sites well above the ground water table. Unless $\mathrm{Na}^{+}$ions are present, it is associated in temperate climates with a forest vegetation and udic soil moisture regime, but not with a steppe vegetation and ustic soil moisture regime. This relationship has been found in many Holocene loess soils in East and Central Europe and in the Central Lowlands and Great Plains of the USA (Bronger, 1976: 35-106; Bronger, 1991, 2003b). Even where illuvation argillans* (Brewer, 1964; Bullock et al., 1985) as unequivocal signs of clay illuviation (Figures $1 \mathrm{~b}$ and 1c) are transformed by changing environmental conditions in buried or relict paleosols, or are aged (Figures 1e and $1 \mathrm{~g}$ ) because of post-pedogenetic or diagenetic processes (which are still poorely understood), they still remain visible as a

*) syn. Braunlehm-Teilplasma (Kubiena, 1956), Fließplasma or birefringing plasma of fine clay (Bronger, 1976), now "coatings of well-oriented clay” (Stoops, 2003; Kühn et al., 2010). 

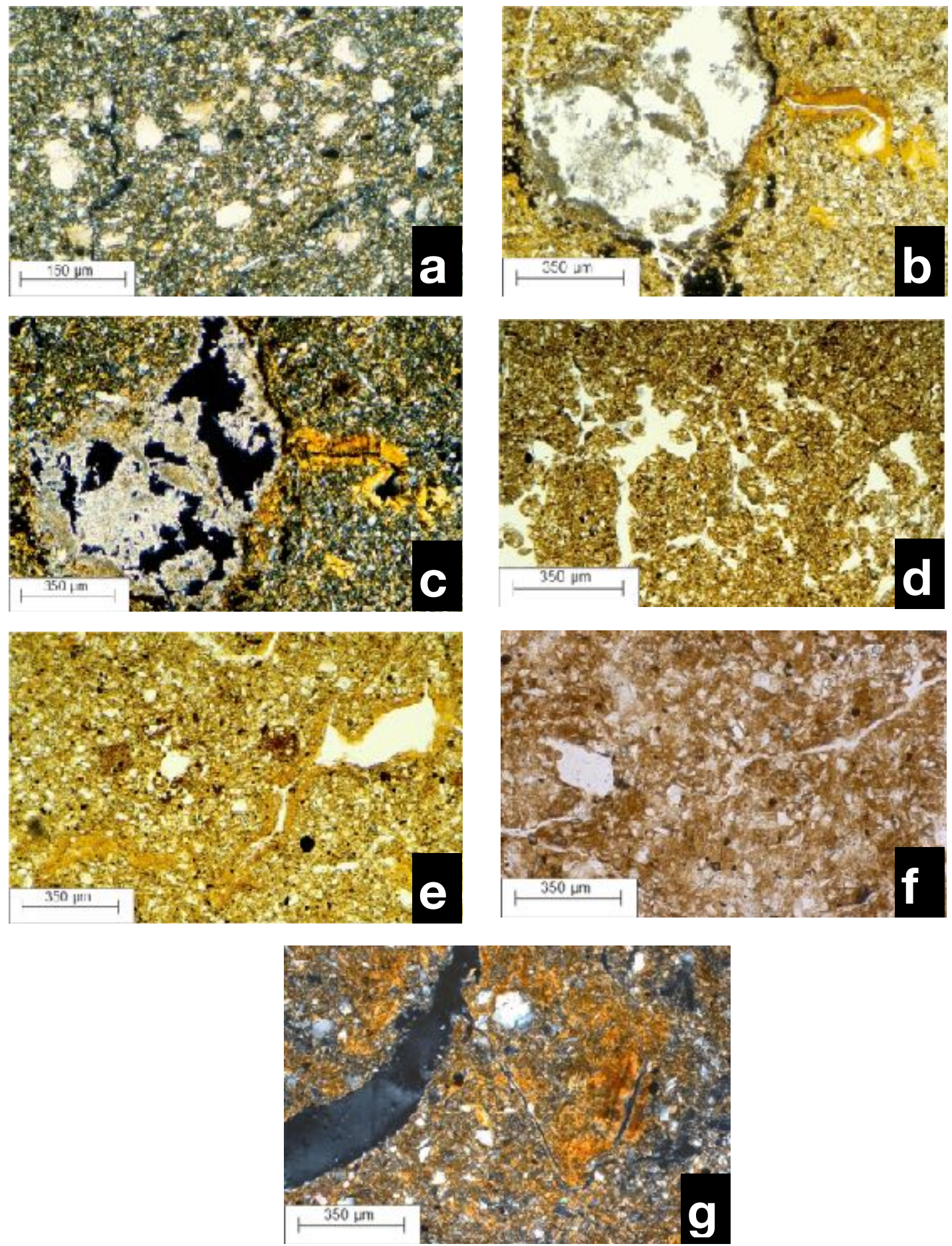

Figure 1 Micromorphology of paleosols in the loess sections of Tadjikistan and Carpathian Basin; a. Primary calcites, irregularly distributed in the matrix, in typical loess above the PK I in Karamaydan; b. Illuviation argillans as a sign of clay illuviation, which took place with pH-values < 6.2, next to later deposited calcite accumulation of the overlying loess as a sign of a polygenetic soil formation. Bt horizon of PK III in Karamaydan; c. Same as 1 b, under $+N$; d. Fine spongy fabric rich in aggregates and pores in the Ah horizon of the PK III in Karamaydan. Most top soils of the pedocomplexes were removed during the solifluction period of the following cold period; e. Strongly aged illuviation argillans in the PK XV (Matuyama epoch) in Chashmanigar; $\mathrm{f}$. Mid pleistocene rubefied earthy Braunlehm (-Lessivé) F6 in Stari Slankamen / Serbia, upper B(t) horizon; g. Same paleosol as 1f, lower part. Small parts of earthened (aged) illuviation argillans, often granulated and inactive in the fabric. 
stable element of soil microfabric. They are even found in the excrements of earthworms (e.g. Zachariae, 1964; photo 3 in Bronger, 1976; photo IA in Catt, 1989) or in "Fließerde" (geliflucted soil) in a buried Mid-Pleistocene Udalf (figures 2A and 2B in Bronger, 1970; photos 1 B-D in Catt, 1989). To summarize, the distinction of primary and secondary calcites and the evidence of clay illuviation enables the recognition of typical loess and the recognition of different genetic soil horizons, such as CB (still with primary calcites), BC, Ah, $\mathrm{Bw}$ and Bt horizons (Figure 2). Figures 3-8 partly summarize our results based on field studies and micromorphological investigations of about 300 thin sections in East and Central Asia, of about 400 thin sections of modern soils and LPS in the Carpathian Basin and several hundred thin sections of LPS in former Czechoslovakia and Lower Austria.

Records of magnetic susceptibility have been used for further paleoclimatic interpretation until recently (e.g. Buggle et al., 2008). Markovic et al. (2011) regarded the "record of magnetic susceptibility (MS) variations as one of the most sensitive loess proxies for paleoclimatic change". However, Maher (1998) already summarized the literature in stating that maxima in magnetic susceptibility values correspond with the paleosols in the Chinese Loess Plateau, in Tadjikistan and in Czechia and minima with the loess layers. In LPS e.g. in Siberia, Alaska and Argentina, however, the complete opposite pattern is found with susceptibility minima corresponding to the most developed pedogenic horizons. Therefore, a paleoclimatic interpretation of magnetic susceptibility records seems at least questionable.

Another approach towards a paleoclimatic interpretation of LPS is the "rubefication intensity (RI) as proxy of the hematite content" (Buggle et al., 2008). Their conclusion that the F6 soil in Stari Slankamen, Serbia (their S5) because of a high RI value is associated with a "mediterranian/

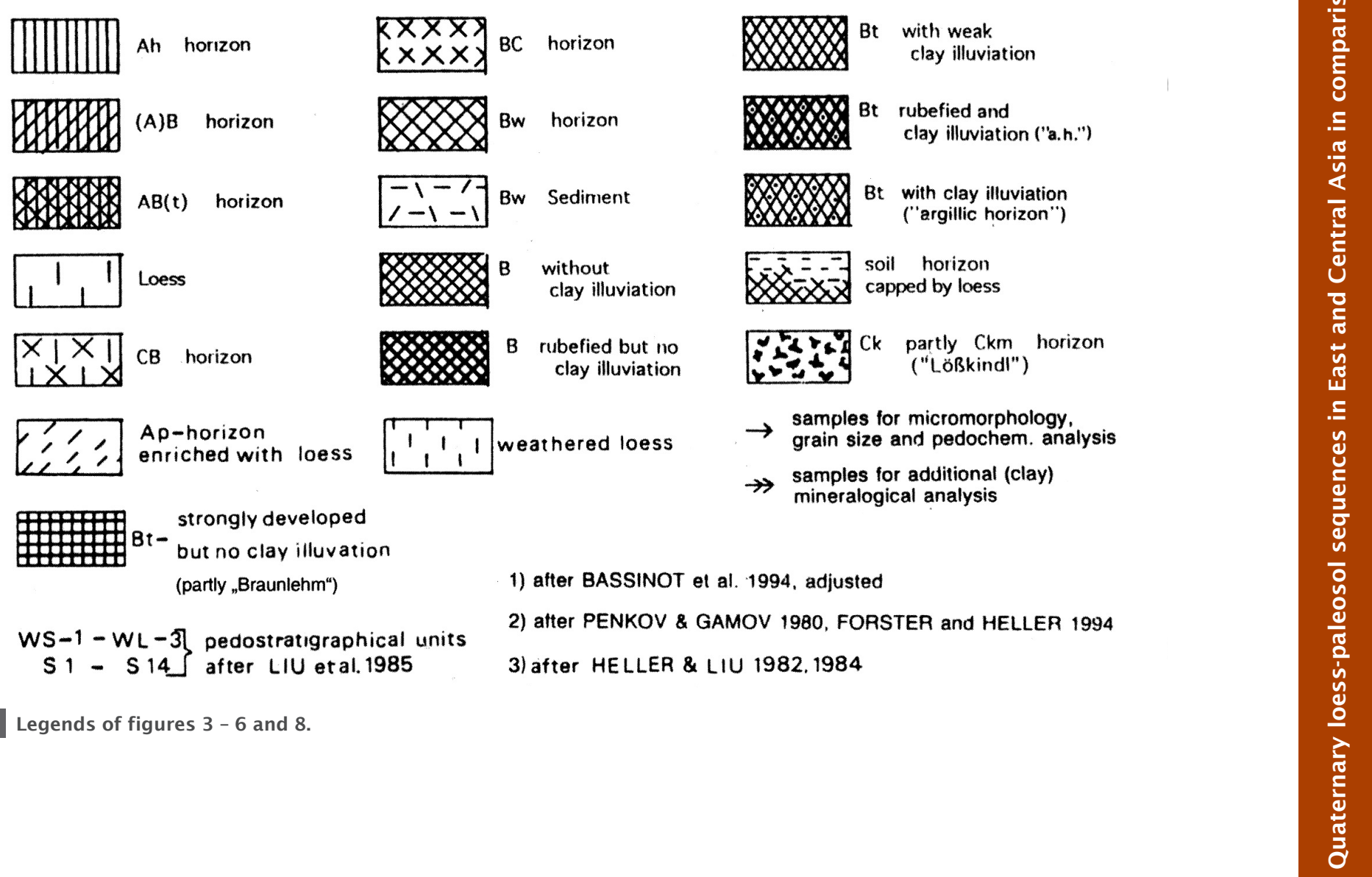


subtropical climate" (their figure 2, p. 18) - which later was even extended to "mid-latitudinal Eurasia" (Buggle et al., 2014: 18) - is no longer valid (see chapter 3.2). Their misinterpretation may have been also caused by an insufficient consideration of the earlier improved chronopedostratigraphy (figure 11 in Bronger et al., 1998a; Bronger 2003a). Also the hematite increase, determined by $5^{\circ} \mathrm{K}$ Mössbauer spectra of the $0.2 \mu \mathrm{m}$ fraction (Bronger et al., 1983) - of Terrae rossae in Slovakia showed that their rubefication is independent of the intensity of weathering (Bronger et al., 1984). In dated 10-30 ka (Zöller, 2000) "Red Soils" in southern Nepal (at the border to India) surprisingly little pedogenetic clay mineral formation could be identified. The hematites, however, are mostly of pedogenic origin. Therefore, the rubefication is a recent autochtonous process and by itself is not a reliable indicator of strong pedogenic weathering (Bronger et al., 2000).

For further paleoclimatic deductions the comparison of the paleosols with the modern soils of the studied region is necessary. Besides the changed lime content (see above) and therefore misleading $\mathrm{pH}$-values in paleosols several other important diagnostic features which can be recognized in modern soils have disappeared or have been changed because of post-pedogenic or diagenetic alteration of the paleosols. For instance, progressive decomposition of organic material with increasing age during the upper Pleistocene in Central Europe (Bronger, 1966, 1974) and even in the Early Holocene in the loess plateau in China (Bronger and Heinkele, 1989; Heinkele, 1990; He Xiubin et al., 2004) prevents the designation of most buried Chernozems (Ustolls) and Phaeozems (Udolls) as Mollisols in the Soil Taxonomy (Soil Survey Staff, 1999).

For further paleoclimatic interpretation other soil-chemical methods of investigation applied to unburied ("modern") soils cannot be used because of post-pedogenic changes in the paleosols. For instance, the $\mathrm{Fe}_{\mathrm{d}}$-values are regarded as "useful tools for the characterization of chemical weathering" (Rohdenburg and Meyer, 1966: 90). So the values of the "active" $\left(\mathrm{Fe}_{\mathrm{o}}\right)$ and "free" $\left(\mathrm{Fe}_{\mathrm{d}}\right)$ iron oxides of four selected Holocene loess soils in the Carpathian Basin (figures 9 and 10) correspond well with the rates of their clay mineral formation. However, these relations are less valid in paleosols with increasing age and sometimes are inverse proportional. As an example the mid-Pleistocene multistory F6 paleosol in Stari Slankamen shows a much higher rate of pedochemical weathering and clay mineral formation than the selected Holocene soils (chapter 3.2; figures 9-11), but the increases of the $\mathrm{Fe}_{\mathrm{o}}$ - and $\mathrm{Fe}_{\mathrm{d}}$-values are even smaller than in the two Holocene Udalfs (for more details see Bronger, 1974, 1976: 13-22).

On the other hand, geochemistry offers a possibility via weathering indices to quantify mean annual precipitation (MAP) and mean annual temperature (MAT) from paleosol horizons via specifically calibrated empirical transfer equations (e.g. Sheldon and Tabor, 2009; Schatz et al., 2015). So for instance Kühn et al. (2013) calculated the MAP during the formation of the last interglacial Bwt horizon of the LPS in Alsheim/ Mainz Basin, Germany on the basis of equation 30 , however, with a standard error (SE) of \pm 235 mm/yr (Sheldon and Tabor, 2009: 16) being $836 \mathrm{~mm}$ (today $613 \mathrm{~mm}$ ), which seems a bit too high. Their calculated MAT of the early Würm Humuszones, loesses and sandy loesses in Alsheim using equation 25 from Sheldon and Tabor (2009) with $\mathrm{SE}$ of $\pm 0.6^{\circ}$ are $9.6^{\circ}$ and $8.7^{\circ} \mathrm{C}$ respectively which are considered as too high by Kühn et al. (2013). Perhaps the unsatisfactory results could be improved by including the Holocene climaphytomorphic soils on loess of the area under investigation in order to get more reliable values of MAP and MAT. In a similar approach Schatz 

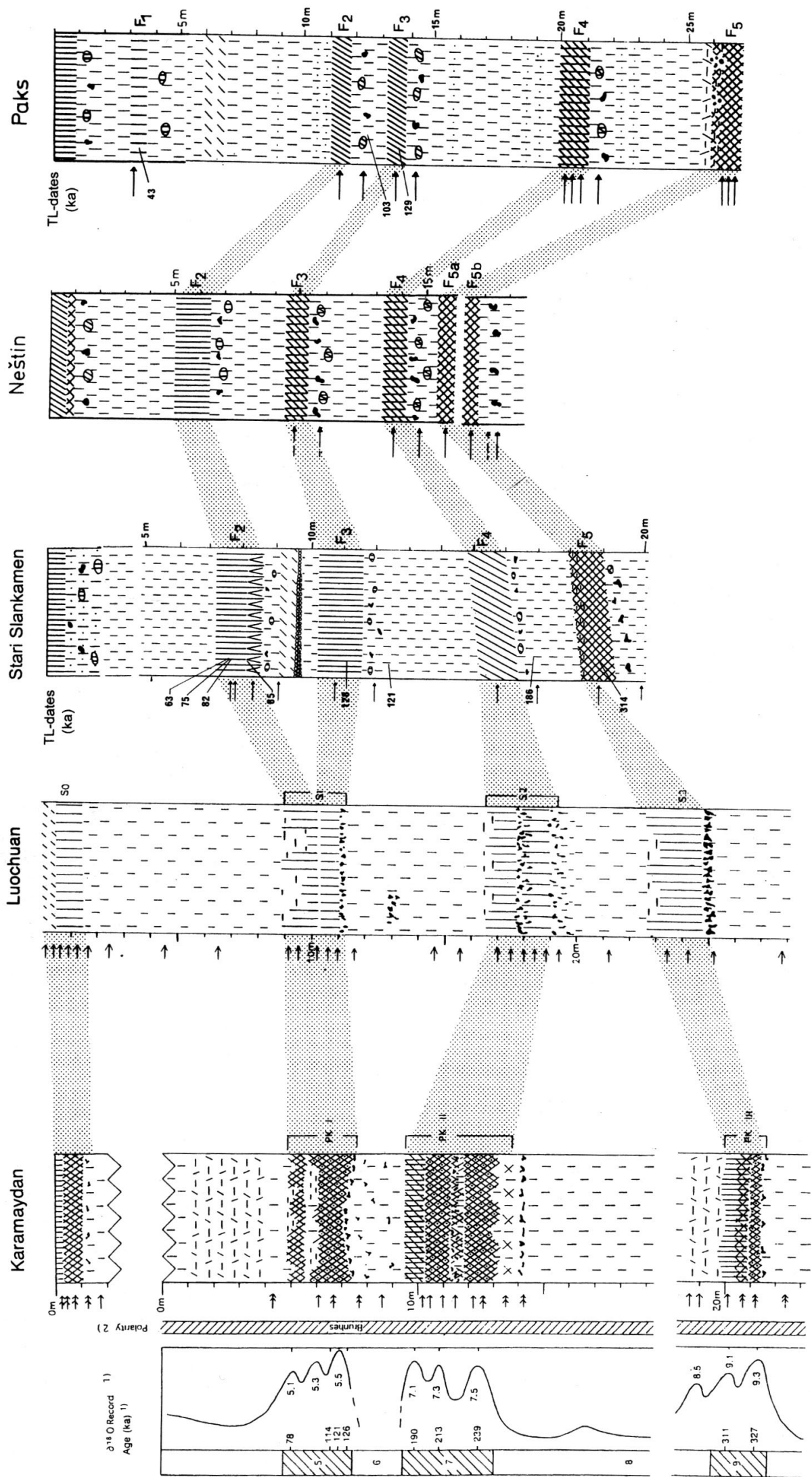
$\frac{0}{\substack{0 \\ n}}$
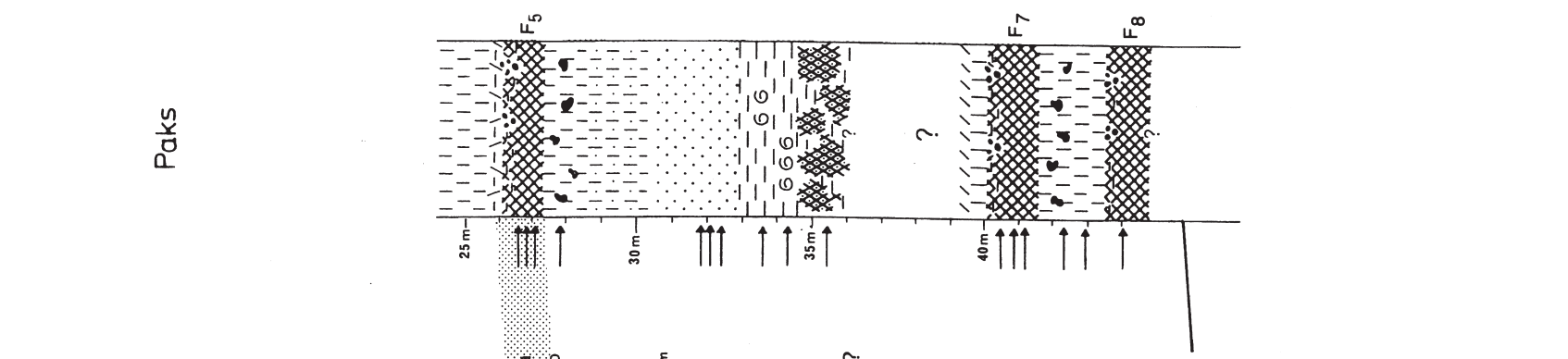

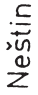

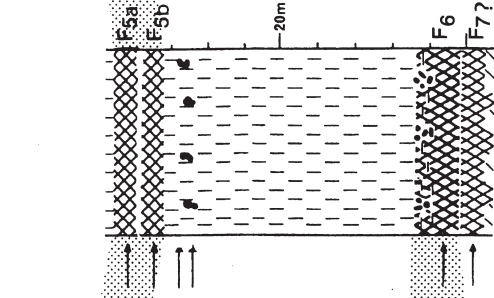

$\frac{\Sigma}{\infty}$

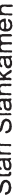

实 후

苋 ญ

ฝ

䨌

ธั บั

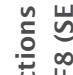

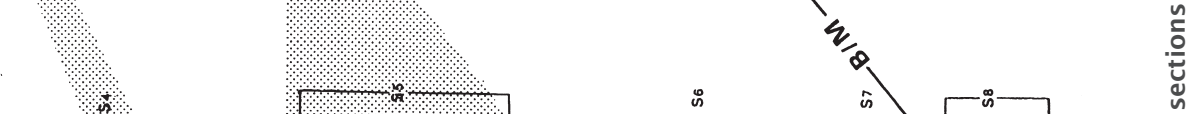

동
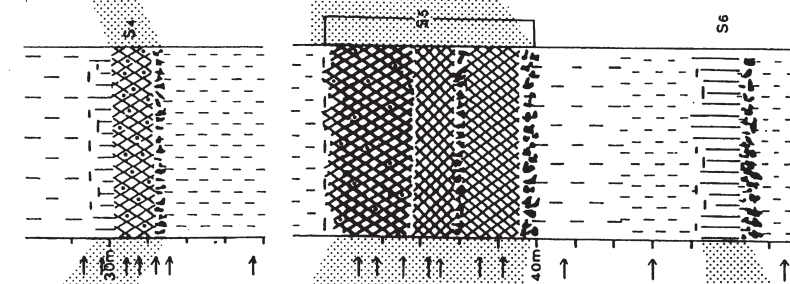

혼

$11+1$ \&@ $\uparrow \quad \uparrow$

$\uparrow \uparrow \uparrow$
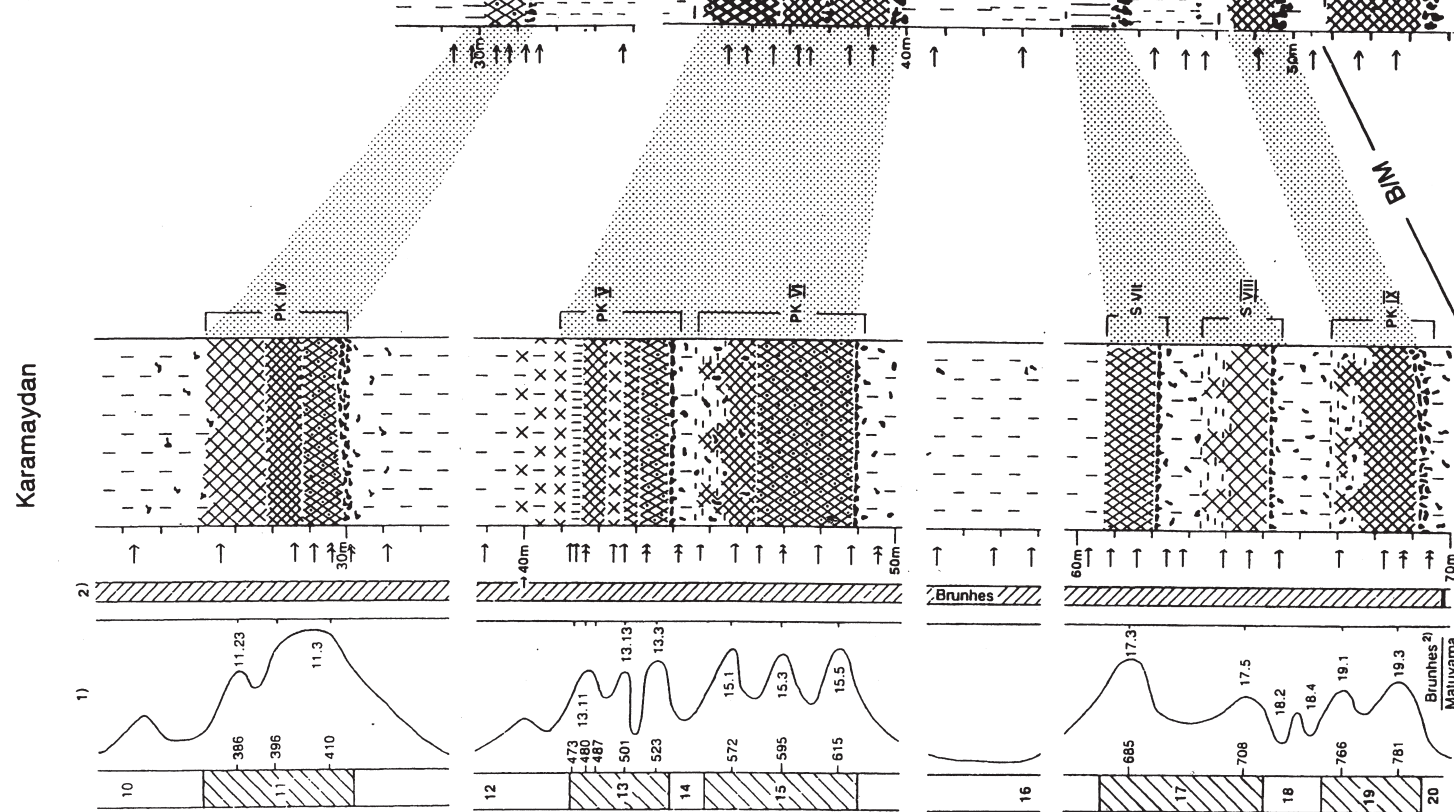
II:
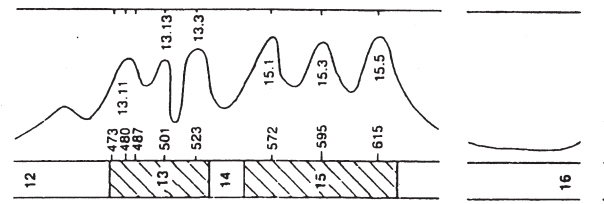

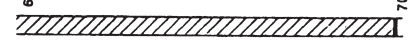

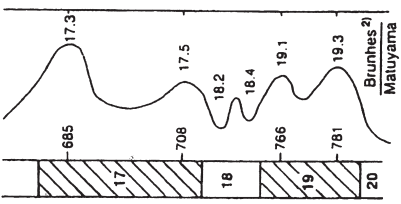


et al. (2015) studied a loess-paleosol sequence near Tokaj (North East Hungary), especially a paleosol, dated 45-27 ka BP. Based on a variety of weathering indices and different transfer functions for major and trace element concentrations (XRF), mass-specific magnetic susceptibility (MS) and stable carbon isotopic $\left(\delta^{13} \mathrm{C}\right)$ data MAT and MAP were calculated. Results converge to a MAT range of $8.5-10^{\circ} \mathrm{C}$ and a MAP range of $700-900 \mathrm{~mm}$ for the paleosol, MS-calculated MAT are $8.4^{\circ} \mathrm{C}$ and MAP 300-500 $\mathrm{mm}$ respectively. These data would have yielded in a distinct weathering of primary minerals and formation of clay minerals. The mineral composition of the silt and clay subfractions of (also partly synsedimentarily formed) loess syrosem "F1" in the loess exposure of Erdut/ Danube, Croatia (Bronger, 1976: 133ff; figure 2 in Bronger, 2003a), dated between $45 \mathrm{ka}$ and 29 ka (Singhvi et al., 1989) show, however, (almost) no mineral weathering and clay mineral formation (Bronger, 1976: 185; esp. tab. V in Bronger et al., 1976: 38-39; figures 5A and 5B in Bronger, 2003a). Therefore, the calculated MAT and MAP during the formation of the paleosol near Tokaj with the same age seem much too high.

Therefore, mineralogical investigations are necessary to indicate the nature and intensity of weathering. To enable paleoclimates the primary and secondary minerals of each fraction, especially that of the clay, must be determined separately. For clay mineralogical investigations it is necessary to separate the clay fraction $(<2 \mu \mathrm{m})$ into coarse $(2-0.2 \mu \mathrm{m})$ and fine clay $(<0.2 \mu \mathrm{m})$, to make semi-quantitative estimations possible (for details see Bronger and Heinkele, 1990; Bronger, 2003a). To evaluate the type and intensity of weathering it is necessary to establish the original petrographic homogeneity of the parent material from which a soil developed. One way of determining this is to use resistant minerals (Barshad, 1967). Quartz is found to be suitable because it is resistant to pedochemical weathering at least in temperate latitudes, and is always abundant in loess. Investigation details of the silt and clay subfractions are given in Bronger et al. (1998a). Figures 9-19 summarize the mineralogical investigations (see chapter 3.2, 3.6); the figures 9 and 11-19 contain also the particle size distribution.

\section{Results and conclusions}

\subsection{KARAMAYDAN / TADJIKISTAN - A KEY SEQUENGE OF THE BRUNHES EPOCH}

The pedostratographical correlation of the loess-paleosol sequences in Tadjikistan and Luochuan / China for the Brunhes epoch (figures 3 and 4) is mainly based on two control points. First, the $\mathrm{B} / \mathrm{M}$ boundary was found in both profiles (Heller and Liu, 1982, 1984; Penkov and Gamov, 1980; Forster and Heller, 1994). Second, the lower soil of the pedocomplex S1 in Luochuan and the lower soil of the PK I in Karamaydan represent the last interglacial or stage 5.5 in the oxygen isotope record. This is supported by TL data of several authors (Nishimura et al., 1984; Liu, 1985: 213-237; Wintle, 1987; Frechen and Dodonov, 1998).

A comparison of the loess-paleosol sequences of Karamaydan and Luochuan for the Brunhes epoch clearly indicates that the sequence in Karamaydan is the more detailed one. To summarize, the loess-paleosol sequence in Karamaydan should be regarded as a key sequence in the temperate climatic belt of the Northern Hemisphere for reconstructing the climate history of the Brunhes epoch.

This conclusion is supported by a correlation with the detailed deep-sea oxygen isotope record of Bassinot et al. (1994), tuned to an accurate astronomical time scale. It allows a detailed 
Karamaydan

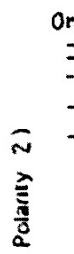

Czechia

(Smolikova 1990)
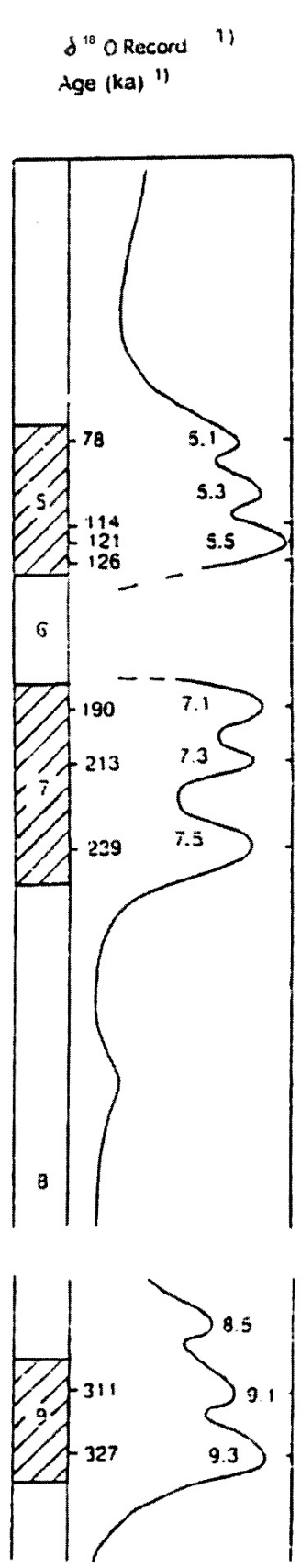

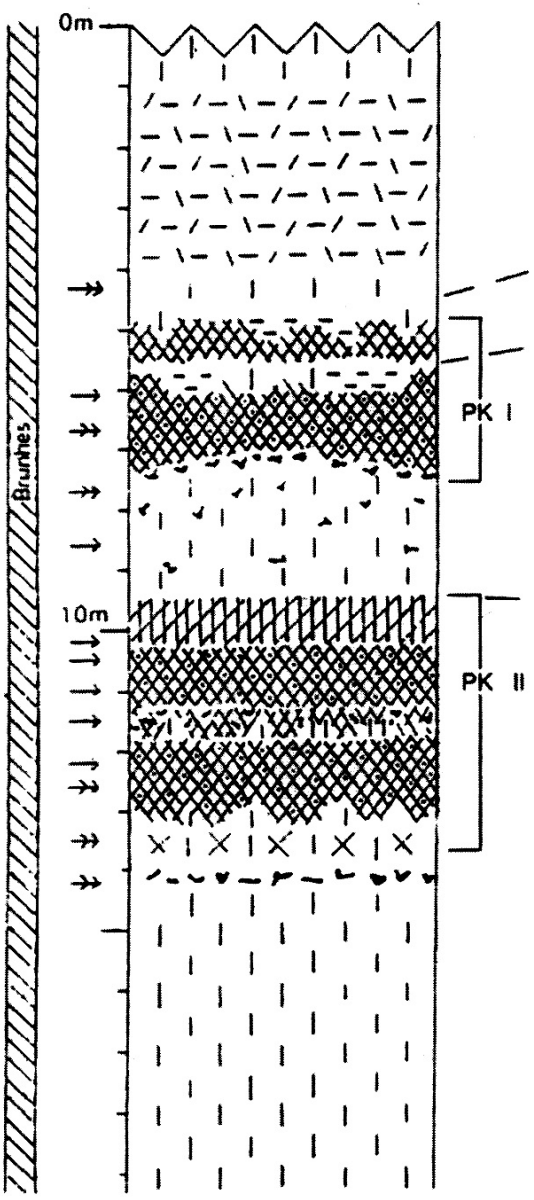

PK I

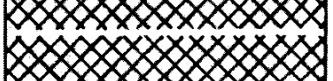

PK
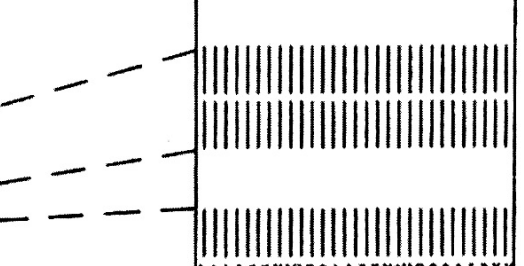

PK III

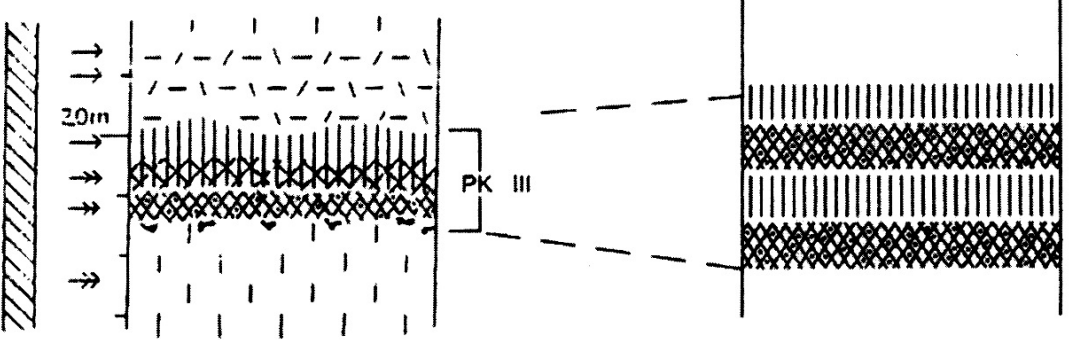


Karamaydan

Czechia

(Smolikova 1990)
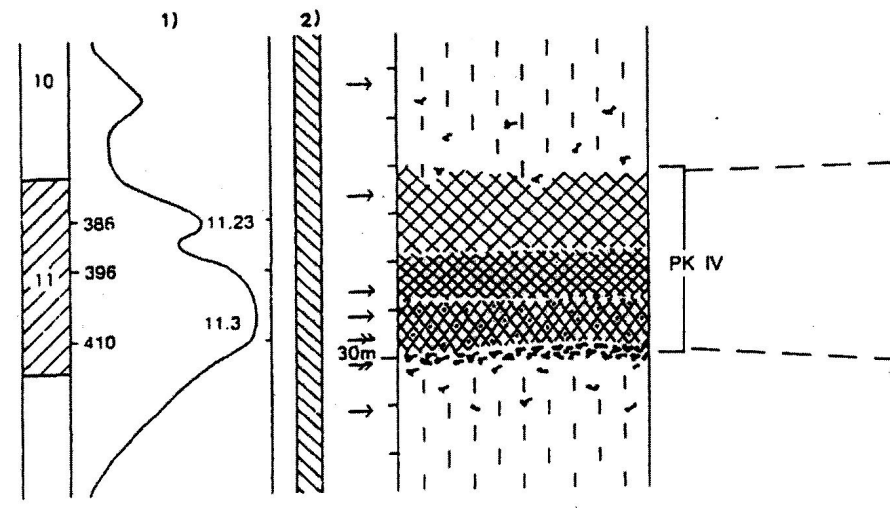

$N \rightarrow+1 \quad 1 \quad 1 \quad 1$

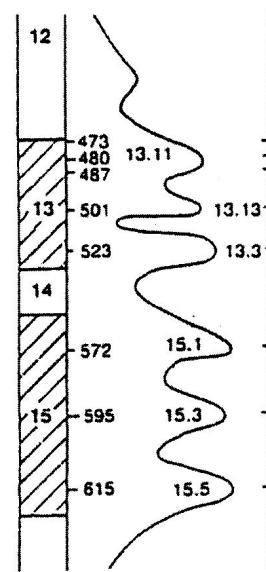

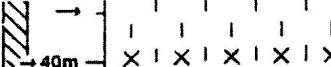

N.

$\Rightarrow \begin{aligned} & 1 \times 1 \times 1 \times 1 \times 1 \times \\ & \Rightarrow \times 10 \times 1 \times 10\end{aligned}$

$\times \times$

$\rightrightarrows \times \times \times \times \times \times \times \times \times x$ PK V

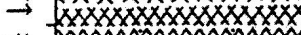

$\rightarrow \quad 0$

$\rightarrow-1=1 ;$

$\rightarrow$
$\rightarrow$
$\rightarrow$
$\rightarrow$
$\rightarrow-10^{\prime}$
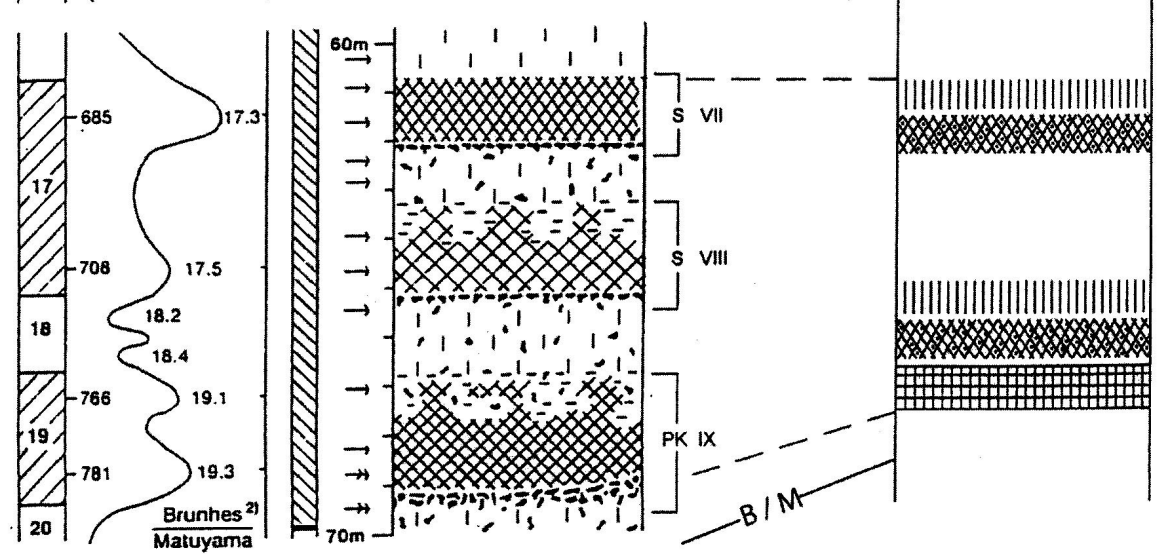

Figure 6 Genesis of paleosols and pedostratigraphic correlation between the sections of Karamaydan / Tadjikistan and the composite section of Czechia in the Brunhes chron (for legend see Figure 2). PK IV - PK IX (Karamaydan) with PK VI - PK X (Czechia). 
chronostratigraphical correlation with the loess-paleosol sequence of the key profile of Karamaydan for the Brunhes chron down to the substage level (figures 3 and 4). The more recent oxygen isotope record of Lisieko and Raymo (2005, 2007), which covers the whole Pleistocene time span down to the Pliocene, however, does not give more information regarding the Brunhes epoch.

The conclusion that the sequence in Karamaydan should be regarded as a key sequence for the Brunhes epoch implies that the loess-paleosol sequences in the Carpathian Basin are less complete than earlier believed (figures 3 and 4). This correlation is again based on the two control points: the $\mathrm{B} / \mathrm{M}$ boundary, found in Paks and Dunaföldvar below the F8 paleosol and recently below the F8 in Stari Slankamen (Pécsi and Pevzner, 1974; Pécsi and Richter, 1996: 222; Hambach in Markovic et al., 2011).

The second control point is the F3 paleosol in the LPS of the Carpatian Basin (figure 2 in Bronger, 2003a, with luminescence dates of A.K. Singhvi)

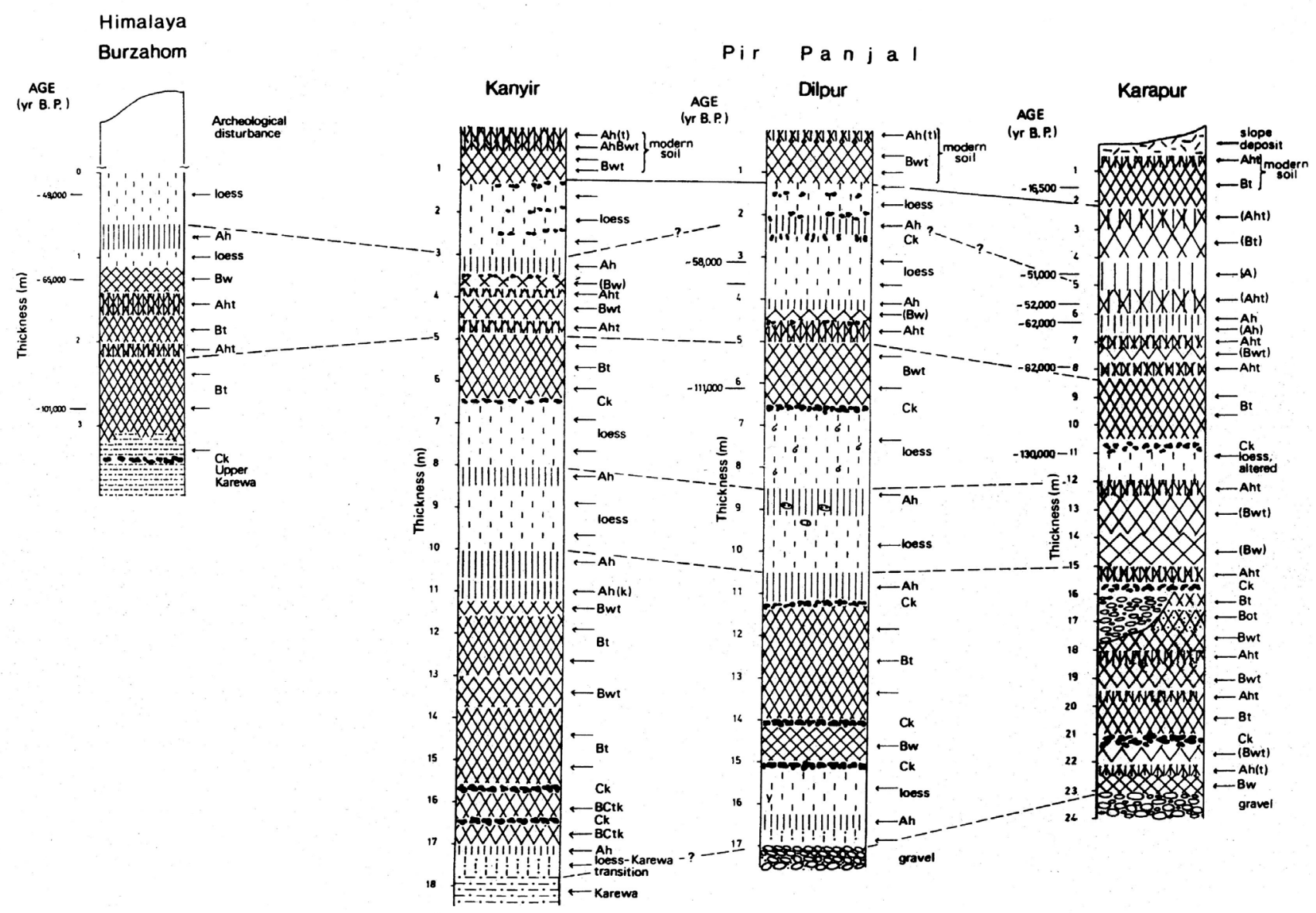

Figure 7 Loess profiles in the Kashmir Basin and their chronostratigraphic relationships. Arrows indicate location where samples for micromorphological study were collected. 


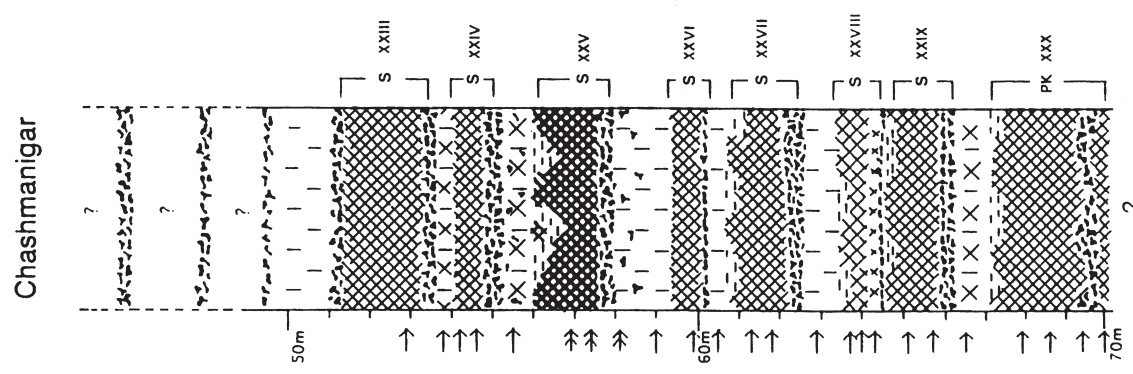

列
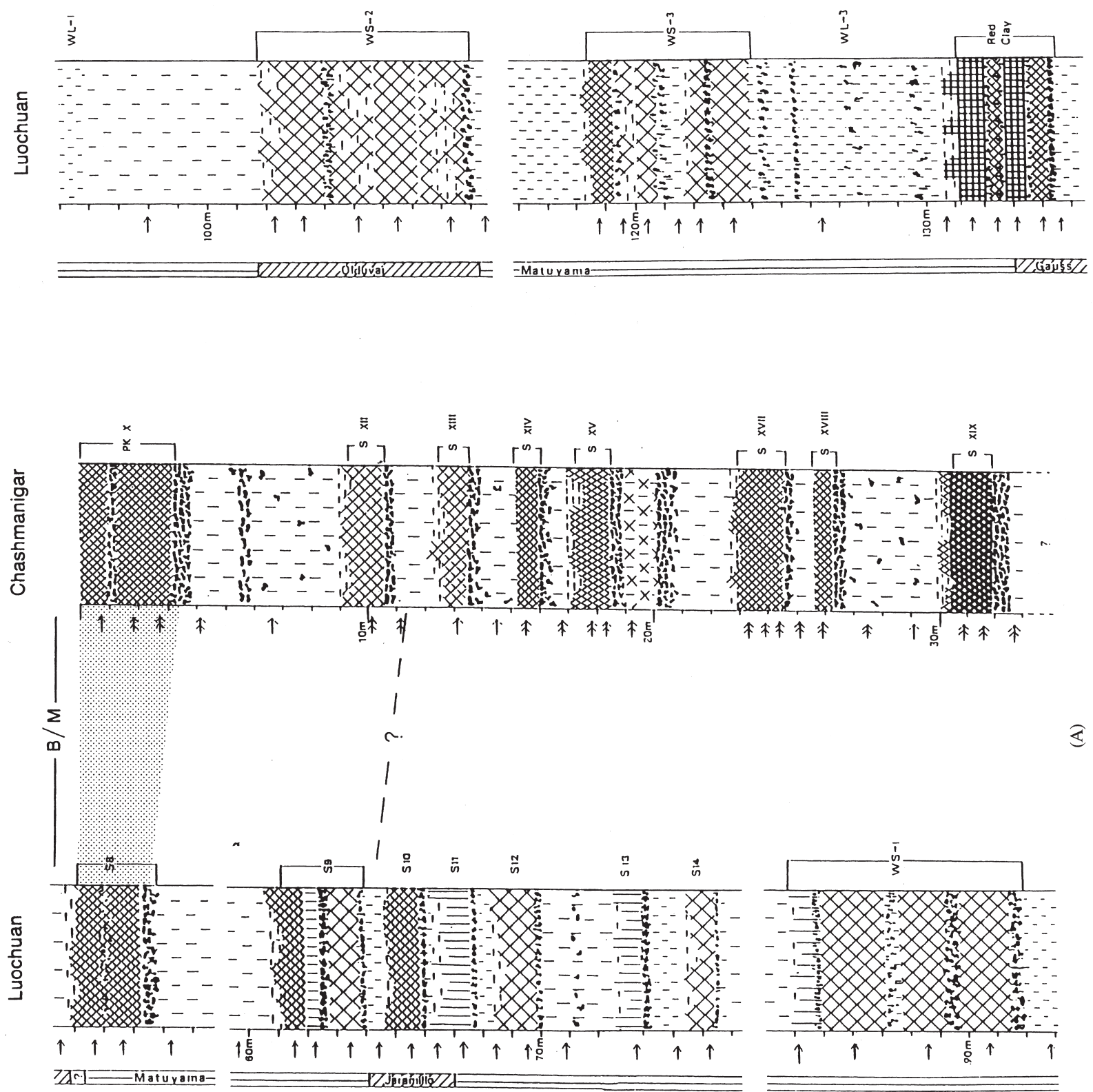
which represents the Riss/Würm interglacial or stage 5.5 in the oxygen isotope record, according to thermoluminescence dates (Wintle and Packman, 1988; Singhvi et al., 1989; Frechen et al., 1997).

\subsection{THE F6 SOIL IN STARI SLANKAMEN: A WELDED OR MULTISTORY PALEOSOL}

An example of the incompleteness of the loess-paleosol sequences in the Carpathian Basin is the very strongly developed F6 paleosol in Stari Slankamen, a rubefied Earthy Braunlehm- (Lessivé) in the sense of Kubiena (1956, 1959) and Smolíková (1967,
1971) (figures 1f and $1 \mathrm{~g}$ ) - with a distinct Ck partly Ckm (loess kindl) horizon. Mineralogical investigations of the silt and clay subfractions show much more pedochemical weathering and clay mineral formation than the Holocene soils in the same area (examples in figures 9 and 10): more than $40 \%$ of the feldspars and almost $80 \%$ of the micas are decomposed (Figure 11); in thin sections only muscovites are found and no biotites remained. This soil was previously believed (Bronger, 1976) to be a soil of the "subtropical soil province" according to Kubiena (1964). It is well preserved in Stari Slankamen but also occurs in Neštin.

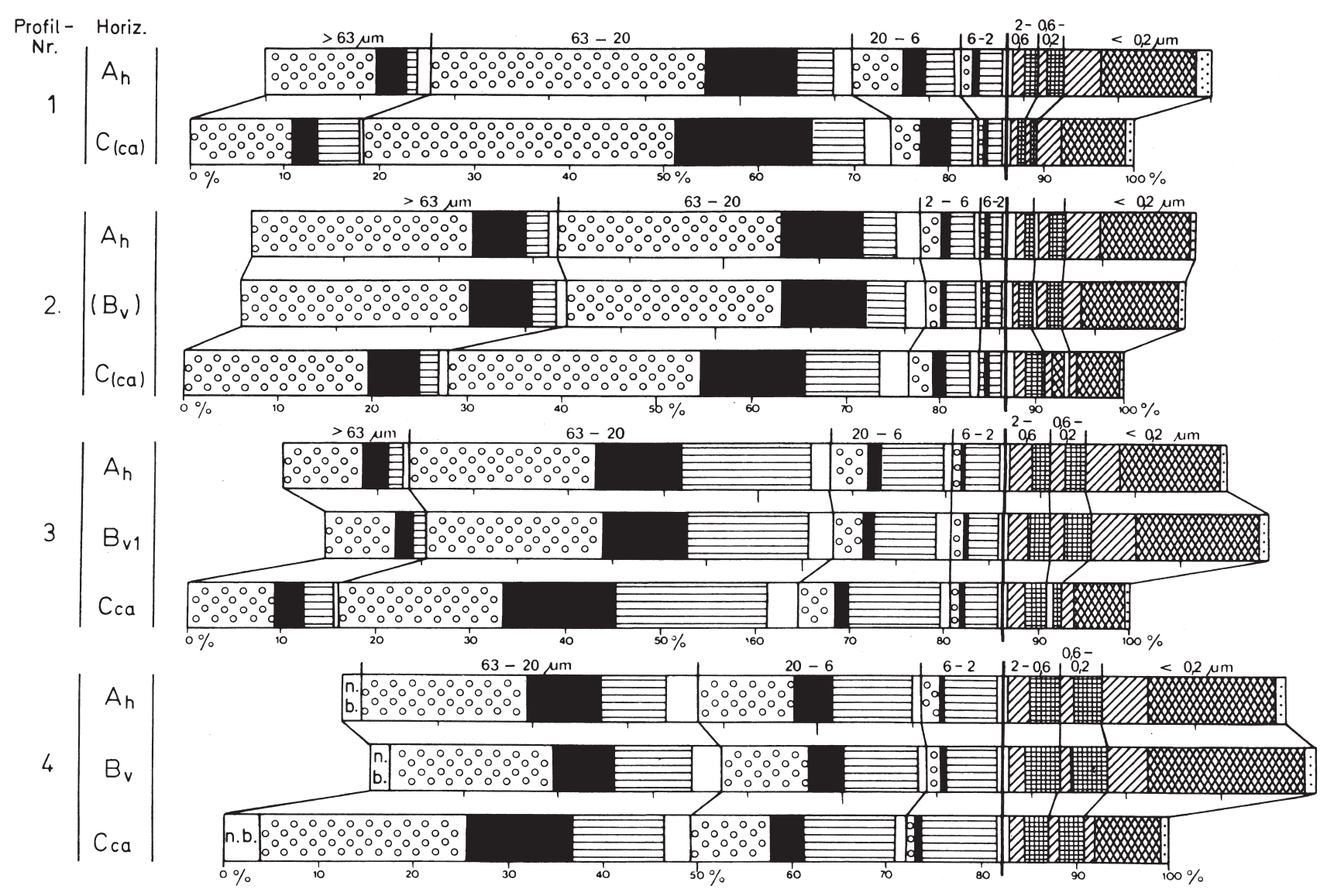

Figure 9 Mineralogical composition of four Holocene loess soils in the Carpathian Basin: two Pachic Haplustolls $(1,2)$ and two Mollic Hapludalfs (3,4). For legend see Figure 12 except phyllosilicates $>2 \mu \mathrm{m}$ : horizontal lines, vermiculites and mixed-layer clay minerals: crossed lines. Mineralogical composition of each particle size fraction. 

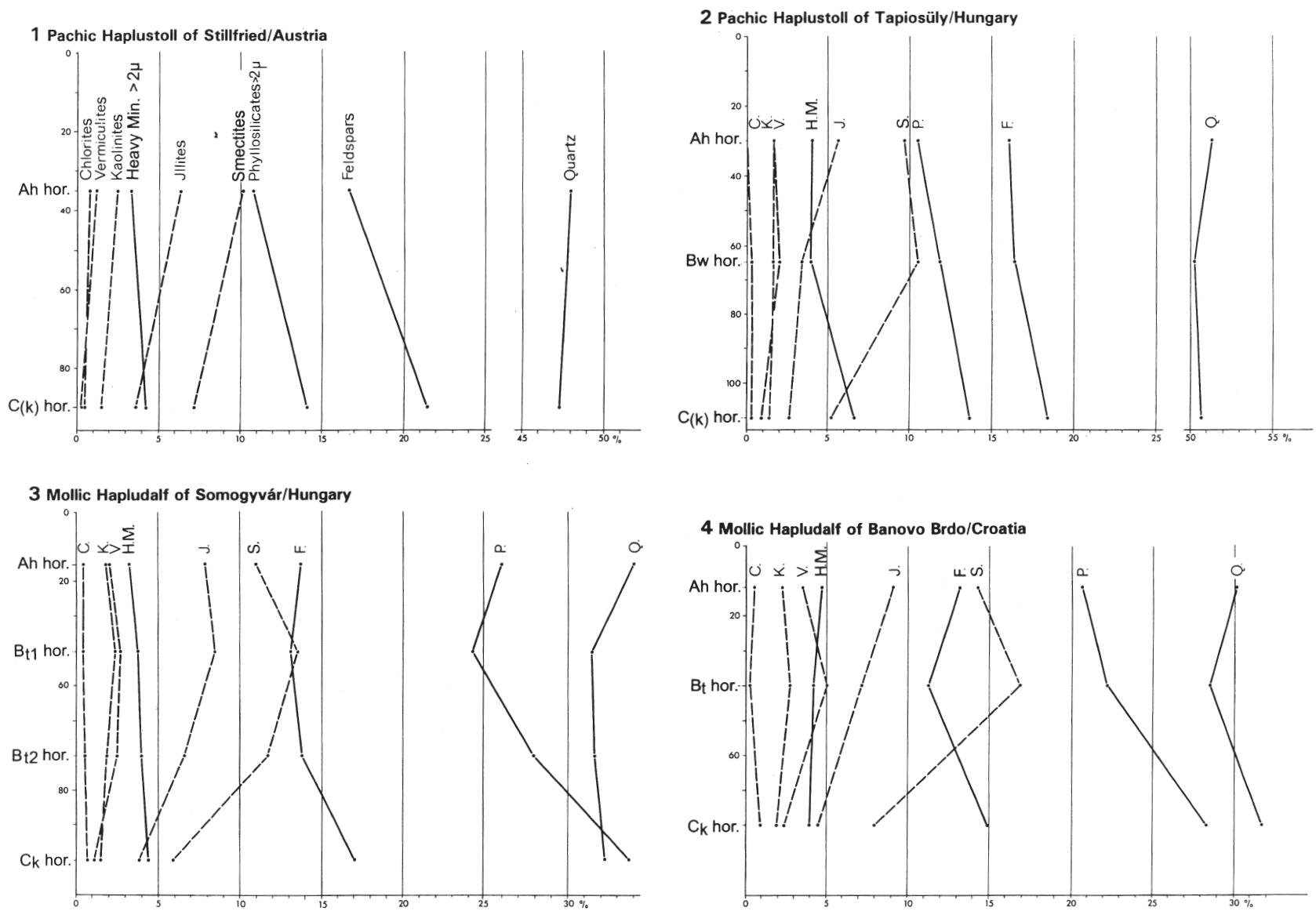

Figure 10 Mineralogical composition of four Holocene loess soils in the Carpathian Basin: two Pachic Haplustolls $(1,2)$ and two Mollic Hapludalfs $(3,4)$. Cumulative curves of the primary minerals $>2 \mu \mathrm{m}$ and the clay minerals.

Later the F6 soil was correlated with the three soils of the S5 pedocomplex in Luochuan (Bronger and Heinkele, 1989) and therefore with the six soils of the two pedocomplexes PK VI and PK V at Karamaydan (Bronger et al., 1998b; see figures 3 and 4). According to the correlation with the OIS curve of Bassinot et al. (1994) the pedocomplexes of PK $\mathrm{VI}$ and $\mathrm{PK} \mathrm{V}$ were formed during $\partial^{18} \mathrm{O}$-substages $15.5,15.3,15.1,13.3,13.13$ and 13.11 in the time span of about 140000 years, although pedogenesis was interrupted several times by loess deposition. This paleosol is therefore an example of a welded (Ruhe and Olson, 1980) or multistory paleosol - as e.g. the paleosol $\mathrm{F} 5$ formed during $\partial^{18} \mathrm{O}$-stages 11 and 9 in a time frame of 415 to $310 \mathrm{ka}$, the F4 and F2 in Stari Slankamen (figures 3 and 4; also chapter 3.4). Mineralogical investigations show only little differences in the type and amount of pedogenic clay mineral formation of selected paleosols in the pedocomplexes VI and V (Figure 15) in comparison with Holocene loess soils (Figure 12), indicating that the climates of the warm phases of PK VI and V were roughly similar to that of the Holocene (cf. chapters 2, 3.6).

\subsection{CORRELATION OF THE SEQUENGE IN KARAMAYDAN WITH THE GOMPOSITE SEGTION IN CZECHIA}

The correlation of the pedocomplexes in Karamaydan with the pedocomplexes of the composite section in Czechia (figures 5 and 6) according to 

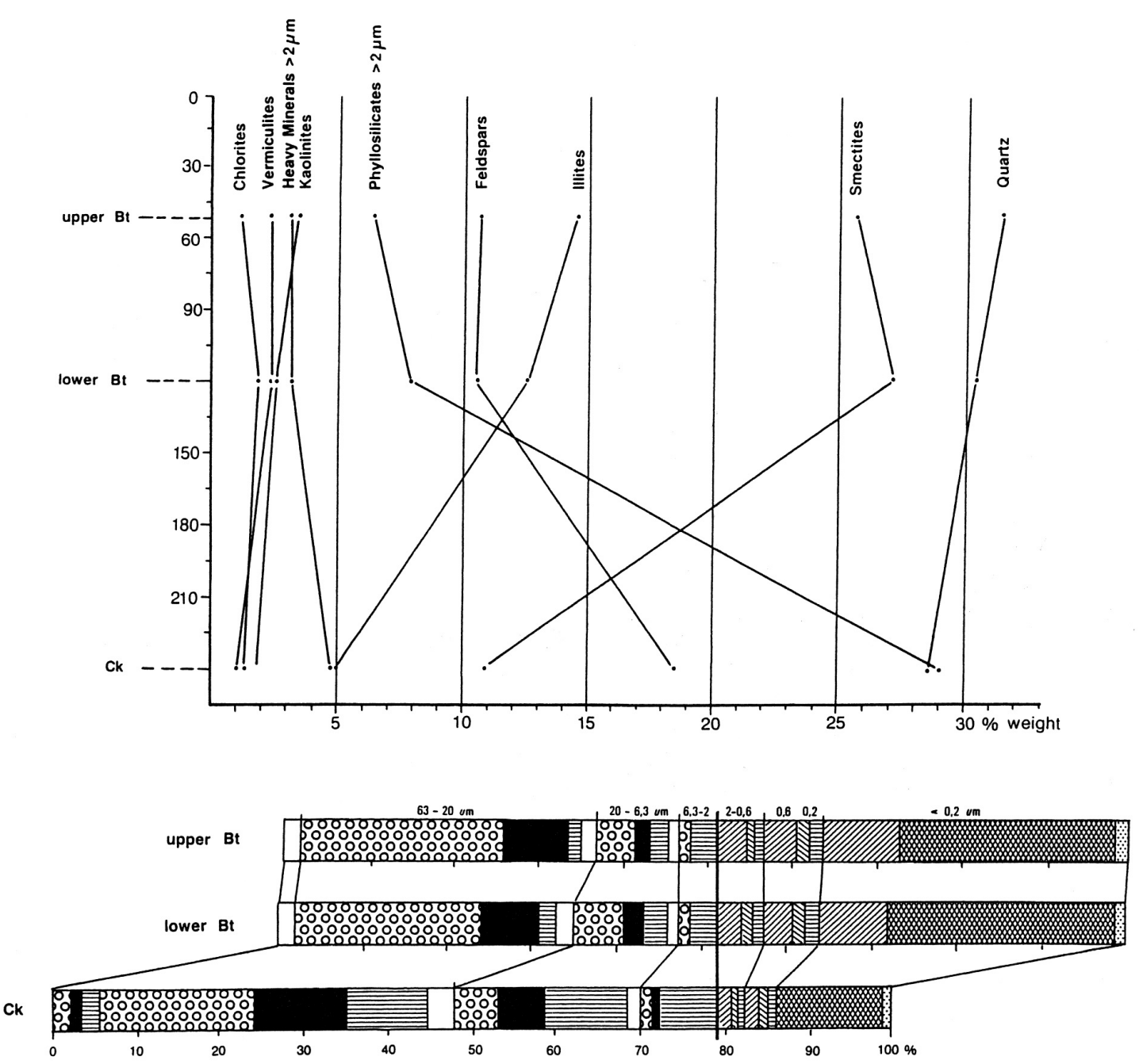

Figure 11 Mineralogical and clay mineralogical composition of the strongly rubefied mid-Pleistocene F6 soil in the loess profile of Stari Slankamen, Serbia. For legend see figures 9 and 12.

Smolíková (1990) in comparison with the single profiles in the Carpathian Basin is straight forward. The two control points of the correlation are the $\mathrm{B} / \mathrm{M}$ boundary found below the $\mathrm{PK} \mathrm{X}$ in Czechia and the lower soil of the PK III in Czechia corresponding with the lower soil of the PK I in Karamaydan, equivalent to stage 5.5 in the OIS. The pedostratigraphical correlation allows an exact time frame of the formation of each pedocomplex in Czechia in the Brunhes chron. So, for instance, the PK IV in Czechia correlated with PK II in Karamaydan was formed in the $\delta^{18} \mathrm{O}$ stages 7.5 to 7.1 between 240000 and 190000 BC.
The PK VIII in Czechia correlated with PK VI in Karamaydan was formed in the $\delta^{18} \mathrm{O}$ stages 15.5 to 15.1 between 615000 and $570000 \mathrm{BC}$.

\subsection{LOESS-PALEOSOL SEQUENGES OF THE EARLY WÜRM PERIOD IN GENTRAL ASIA IN COMPARISON WITH GENTRAL EUROPE}

Above the last interglacial F3 paleosol in the Carpathian Basin, there is only one strongly developed paleosol F2 (figures 3 and 4). At Karamaydan and Luochuan, the upper soils of the PK I- and S1- pedocomplex are the only strongly developed 
paleosols formed in the early Würm period, which is chronostratigraphically equivalent to $\delta^{18} \mathrm{O}$ substages 5.3-5.1. However, in several loess exposures in the Central Asian Kashmir Valley (India), which today has a xeric soil moisture regime like that of Tadjikistan, three distinct $\mathrm{Ah}$ or Aht horizons, each $30-50 \mathrm{~cm}$ thick and separated by loess or loess-like sediments, are preserved above the last interglacial Bt horizon (Bronger et al., 1987; see Figure 7). They were formed in the time interval between 80 and $50 \mathrm{ka}$ (Singhvi et al., 1987).

These Ah/Aht horizons correspond well with the three Ah horizons of the upper PK III and the PK II - all free of primary calcites- in Dolni Veštonice
/ Czechia (Bronger, 1976: 146-149). In western parts of Central Europe such as the Netherlands, Belgium and western parts of Germany, three distinct "Humuszonen" above the last interglacial soil are exposed in loess sections (e.g. Semmel, 1989, 1999; Bibus, 1999; Kühn et al., 2013) covering the time interval between 110 and 65 ka (Zöller, 1995; Frechen and Preusser, 1996). The lower and, on a minor scale the middle "Humuszone" in MainzWeisenau display characteristic molluscs of warm phases, among them several dedicated woodland species (Bibus et al., 2002). Therefore the well-developed F2 soil exposed in many places in the Carpathian Basin (Bronger, 1976; figure 2 in Bronger,
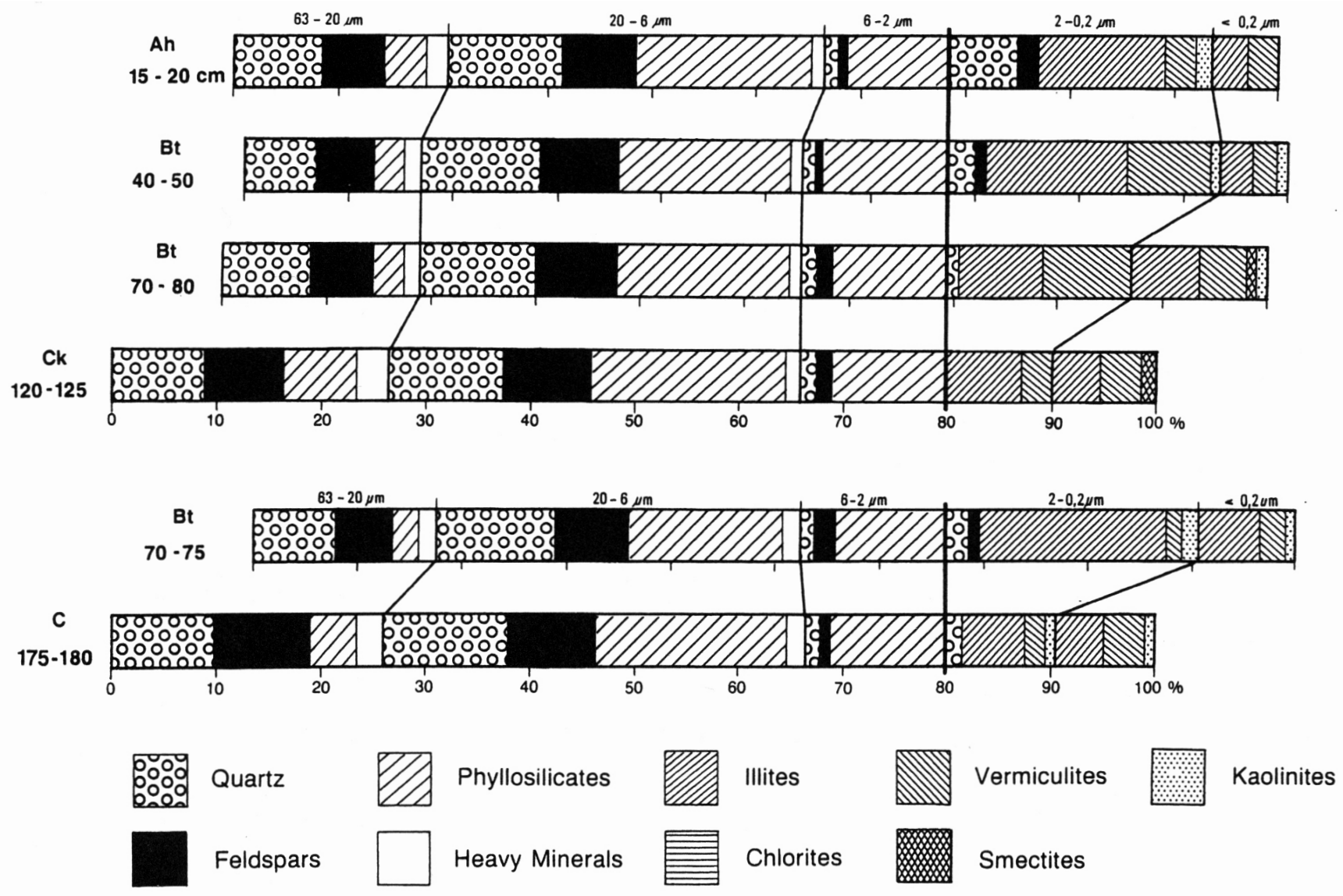

Figure 12 Mineralogical composition of the silt and clay subfractions of two Holocene soils (Typic Haploxerolls or Haplic Phaeozems) in the Tadjik Depression (1700 $\mathrm{m}$ above sea level). 

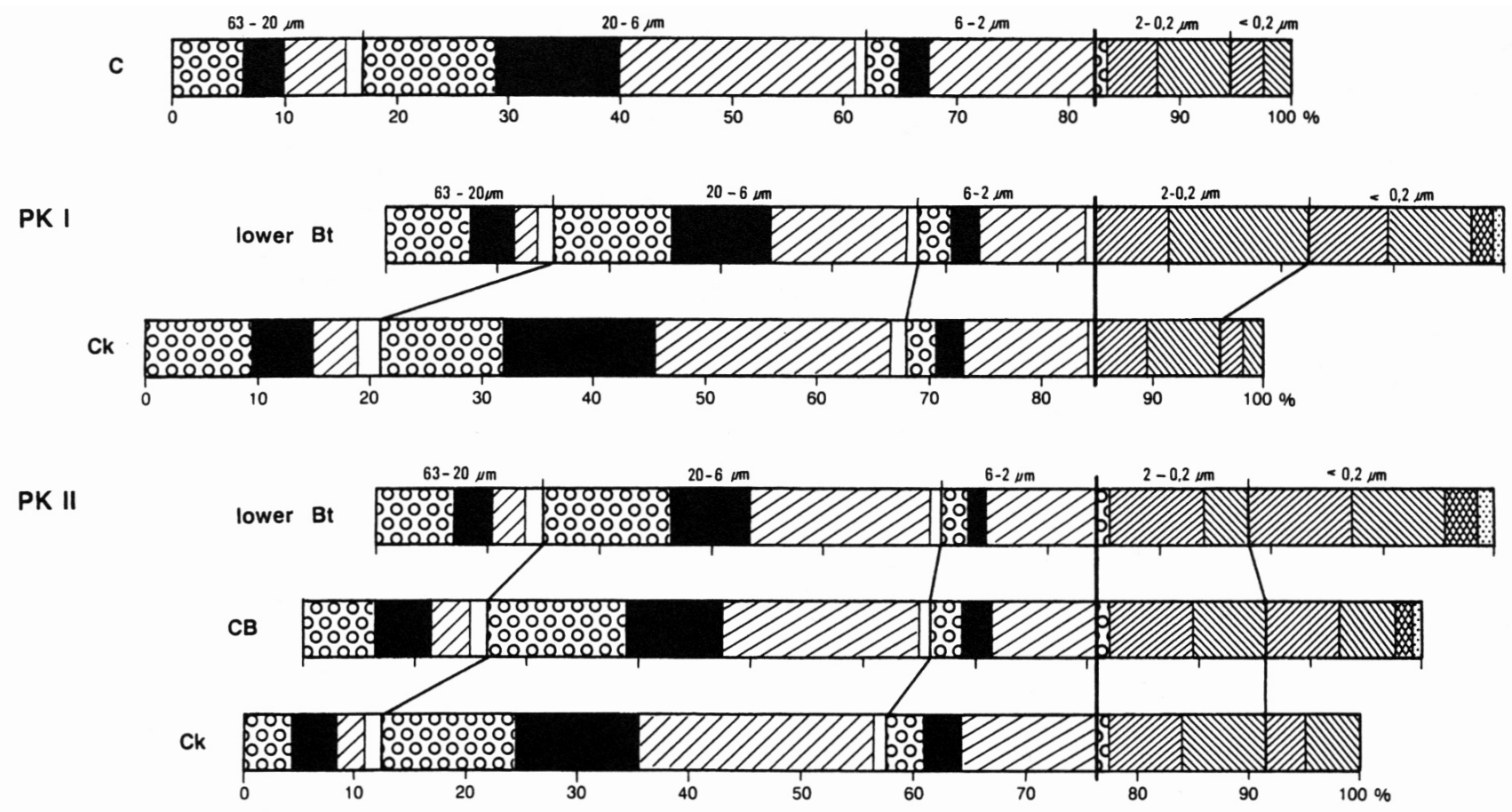

Figure 13 Mineralogical composition of the silt and clay subfractions of pedocomplexes (PK) I and II in the loess profile of Karamaydan (Tadjk Depression). For legend see Figure 12.

2003a) and its chronostratigraphical equivalents at Karamaydan and Luochuan must be regarded as multistory paleosols.

\subsection{LOESS-PALEOSOL SEQUENGES OF THE MATUYAMA EPOCH}

For the Matuyama epoch, a paleomagnetic chronostratigraphical time frame of the LPS is provided by Heller and Liu (1982, 1984), but only for the Luochuan section. Figure 8 therefore can only compare the central and lower parts of the Luochuan and Chashmanigar sections. It shows that the central and lower LPS sequence at Chashmanigar, which represents most of the Matuyama epoch probably down to the Olduvai event (Dodonov, 1986, 1991), contains many more pronounced paleosols (about 20) than the equivalent parts at Luochuan. This is especially apparent in the Wusheng loess at Luochuan, which contains only synsedimentarily formed paleosols ('WS1-WS 3', see Figure 8).

It is astonishing that Dodonov and other authors, who worked in Tadjikistan (summarized in Bronger et al., 1995) did not even mention the very distinct $\mathrm{Ck}$ (loess kindl) horizons (e.g. Figure 20 ) in their figures (also Pécsi and Richter, 1996: 175). Most paleosols have lost at least their topsoils during the solifluction period of the following cold period. Sometimes the whole paleosol is eroded, only the $\mathrm{Ck}$ horizon, more resistant to soil erosion, remains from the former soil formation (examples in Figure 8B).

In the Carpathian Basin only at Stari Slankamen are three strongly developed though truncated rubefied Braunlehms (in the sense of Kubiena) 

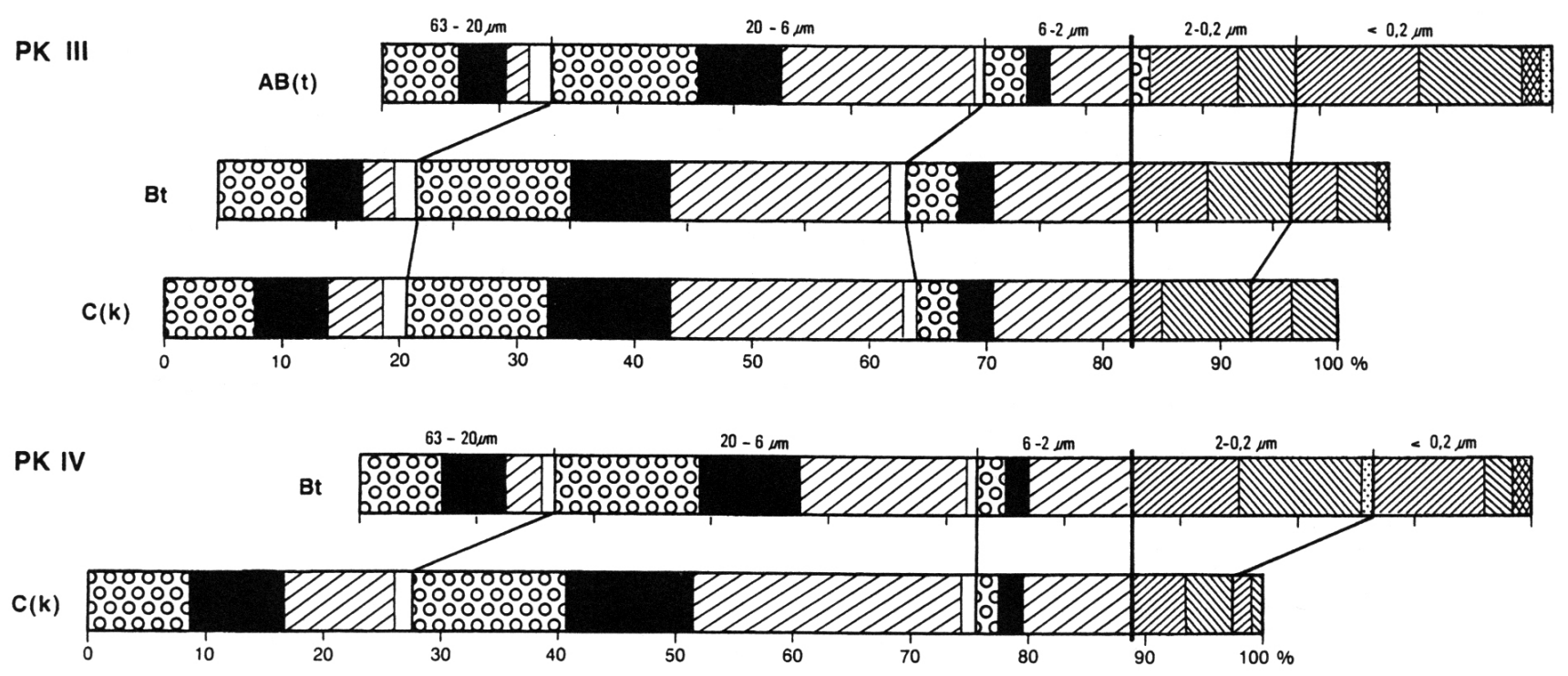

Figure 14 Mineralogical composition of the silt and clay subfractions of pedocomplexes (PK) III and IV in the loess profile of Karamaydan (Tadjik Depression). For legend see Figure 12.
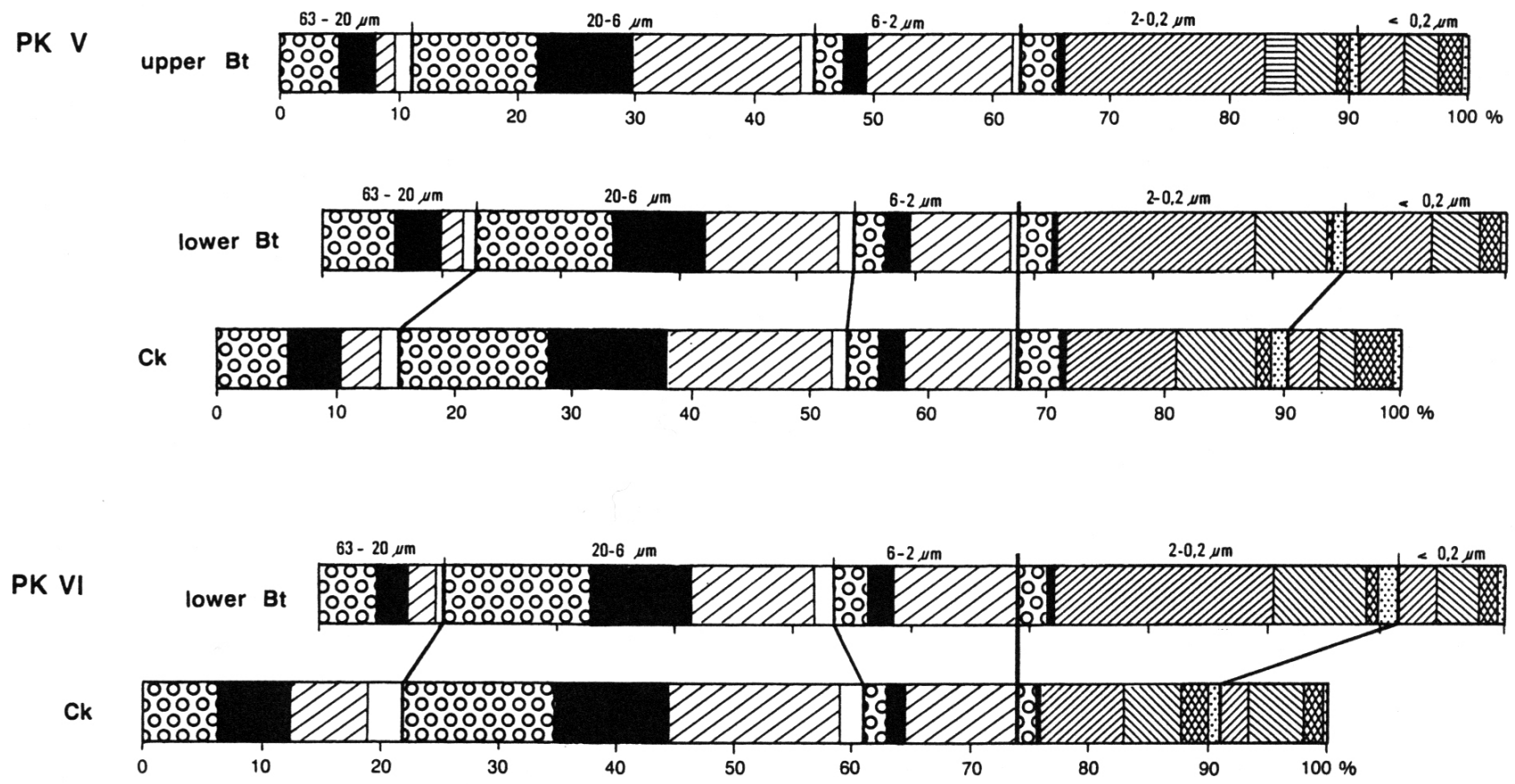

Figure 15 Mineralogical composition of the silt and clay subfractions of pedocomplexes (PK) V and VI in the loess profile of Karamaydan (Tadjik Depression). For legend see Figure 12. 
F9-F1 1 above Neogene sediments (Bronger, 1976, 2003a), in Lower Austria, however, several more paleosols mostly classified as Braunlehms, rubefied Braunlehms and Rotlehms are exposed, especially in Stranzendorf and Krems-shooting range (Fink and Kukla, 1977; Smolíková et al., 2010; Sprafke, 2016).

\subsection{ADDITIONAL MINERALOGY: PALEOGLIMATIC DEDUGTIONS}

The results of the mineralogical investigations of the three silt and two clay subfractions of selected paleosols in Karamaydan and Chashmanigar / Tadjikistan and for comparison with Holocene loess soils of this area are summarized in figures 12-19. Some points worth emphasizing are the following:

1. The percentage of quartz by weight in the silt fractions increases only slightly between the $\mathrm{C}$ or $\mathrm{Ck}$ and the overlying $\mathrm{B}$ or Bt horizons in almost all $\mathrm{PKs}$ and $\mathrm{Ss}$, thus indicating original petrographic homogeneity. However, the change in the quartz content from 19.5 to $23.5 \%$ in S XVI and especially from $21 \%$ to $26 \%$ in S XII at Chashmanigar (Figure 8) shows a greater petrographic inhomogeneity in these paleosols.

2. The main sources of pedogenic clay minerals are phyllosilicates in the silt fractions: in most of the paleosols and the Holocene soils there is a considerable decrease in silt-size micas in the $\mathrm{B}$ or Bt horizons compared with the $\mathrm{Ck}$ horizons. Feldspars are a minor source of the pedogenetically formed clay minerals (figures 12-19).

3. There is little difference in the type and amount of pedogenic clay mineral formation between the Holocene soils and the buried paleosols (B or Bt horizons) of the Brunhes epoch at Karamaydan and of the Matuyama epoch at Chashmanigar. The amount of pedogenic clay mineral formation in the Quaternary soils is mostly in the range of 10 to $15 \%$. Only in the lower $\mathrm{Bt}$ horizons of PK I and IV at Karamaydan it is as large as 20\% (figures 13 and 14). Together with the higher amount of illuviation argillans in these soils it can be concluded that the climates in these

PK IX

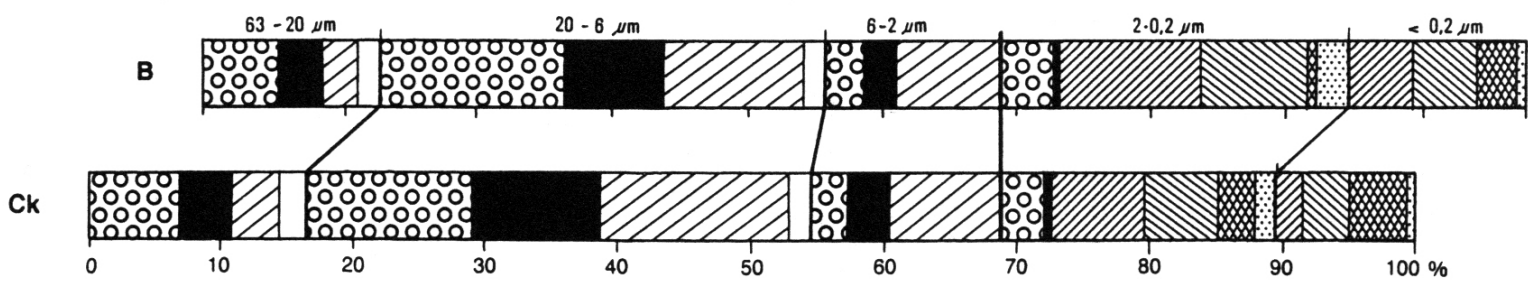

PK XII

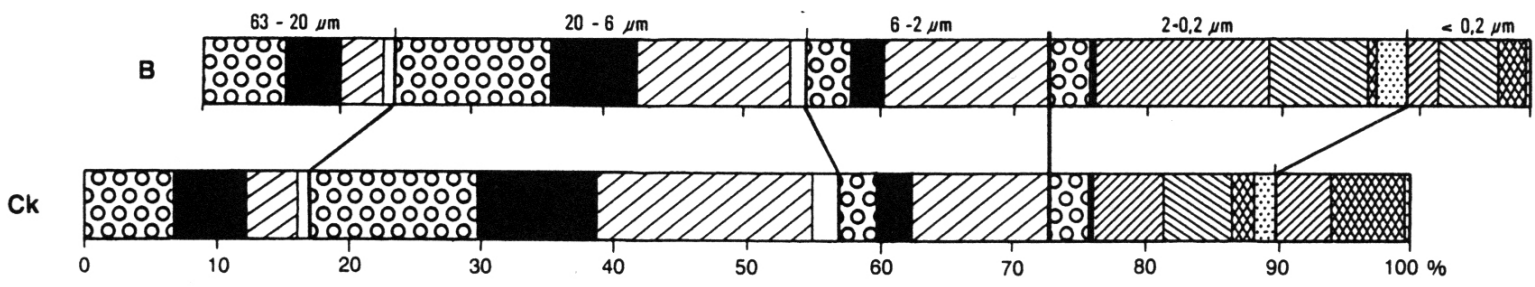

Figure 16 Mineralogical composition of the silt and clay subfractions of pedocomplexes (PK) IX and XII in the loess profile of Karamaydan (Tadjik Depression). For legend see Figure 12. 

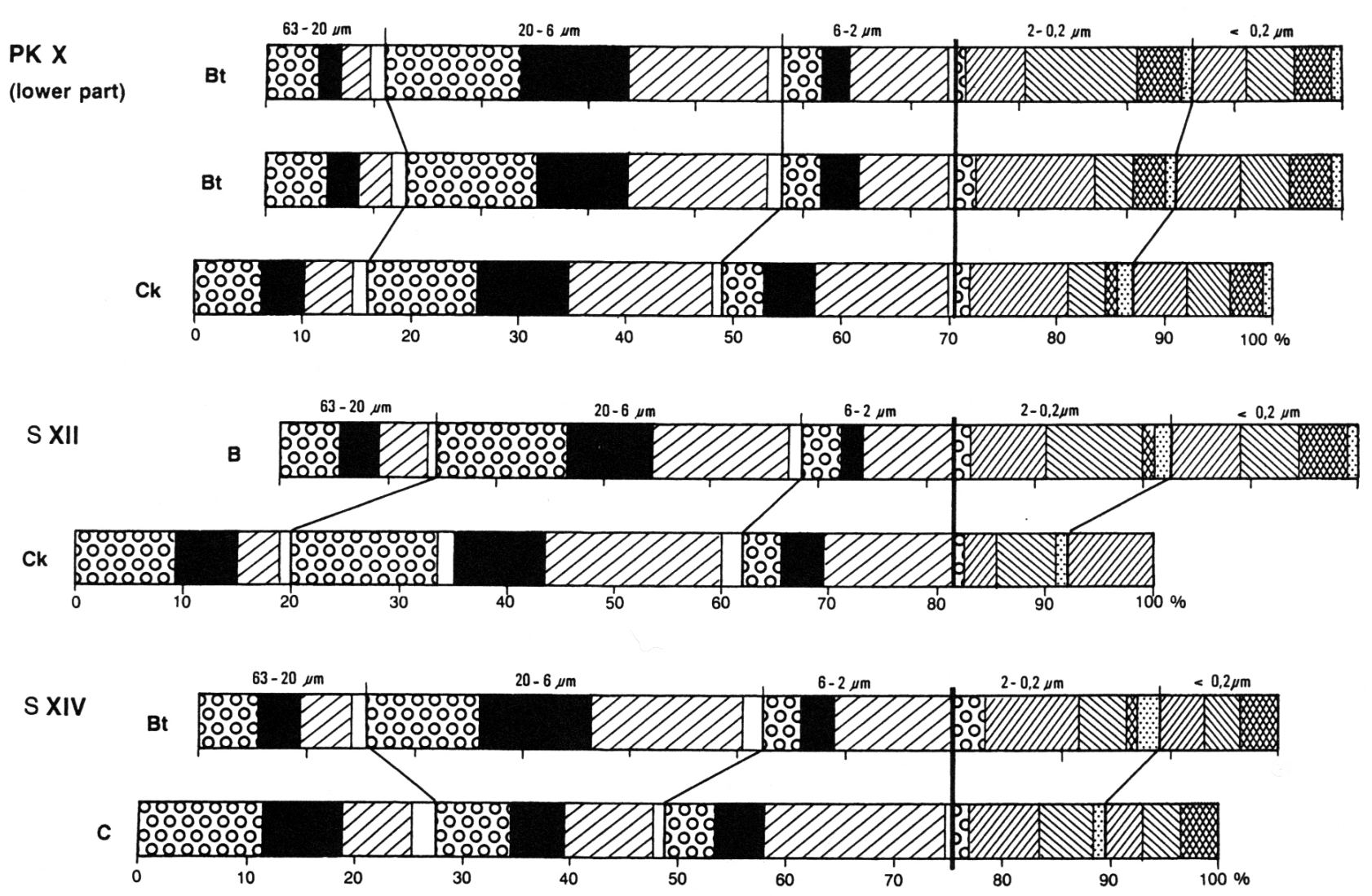

Figure 17 Mineralogical composition of the silt and clay subfractions of pedocomplex (PK) X and paleosols S XII and S XIV in the loess profile of Chashmanigar (Tadjik Depression). For legend see Figure 12.

interglacials were moister than in the Holocene. This is in agreement with e.g. the area of Southern Moravia / NE Lower Austria: in Dolni Veštonice the last interglacial soil (OIS 5.5) is a Luvisol or Typic Udalf with distinct illuviation argillans (photo 21, 22 in Bronger, 1976), whereas modern loess soils in this area are Calcic Chernozems (Fink, 1964; Hrasko et al., 1973, Bronger, 1976: Stillfried soil; table 1 in Bronger et al., 1976). A limited amount of pedogenic clay mineral formation $(10-15 \%)$ is also typical for the lower paleosols of the Matuyama epoch in the Chashmanigar section, although S XIX and S XXV, which are more rubefied soils (Figure 8), seem to be more strongly developed than the other paleosols. However, the clay mineralogical composition of the Bt horizons of S XIX and S XXV could only be compared with the (B)Ck horizons immediately beneath.
These results, briefly summarized here, suggest that the interglacial climates represented by the $\mathrm{B}$ or Bt horizons of the buried paleosols of late, middle, and early Pleistocene age were roughly similar to that of the Holocene. Therefore the partly rubefied Braunlehms, and Rotlehms of old Pleistocene age in the Carpathian Basin and in Lower Austria must be regarded as multistory paleosols.

\section{Discussion remarks}

1. The LPS of Chashmanigar described by Dodonov (1986, 1991) and Pécsi und Richter, (1996: 175) with paleomagnetic data probably down to the Olduvai event, was covered in 1992 by a big landslide. Therefore paleomagnetic 

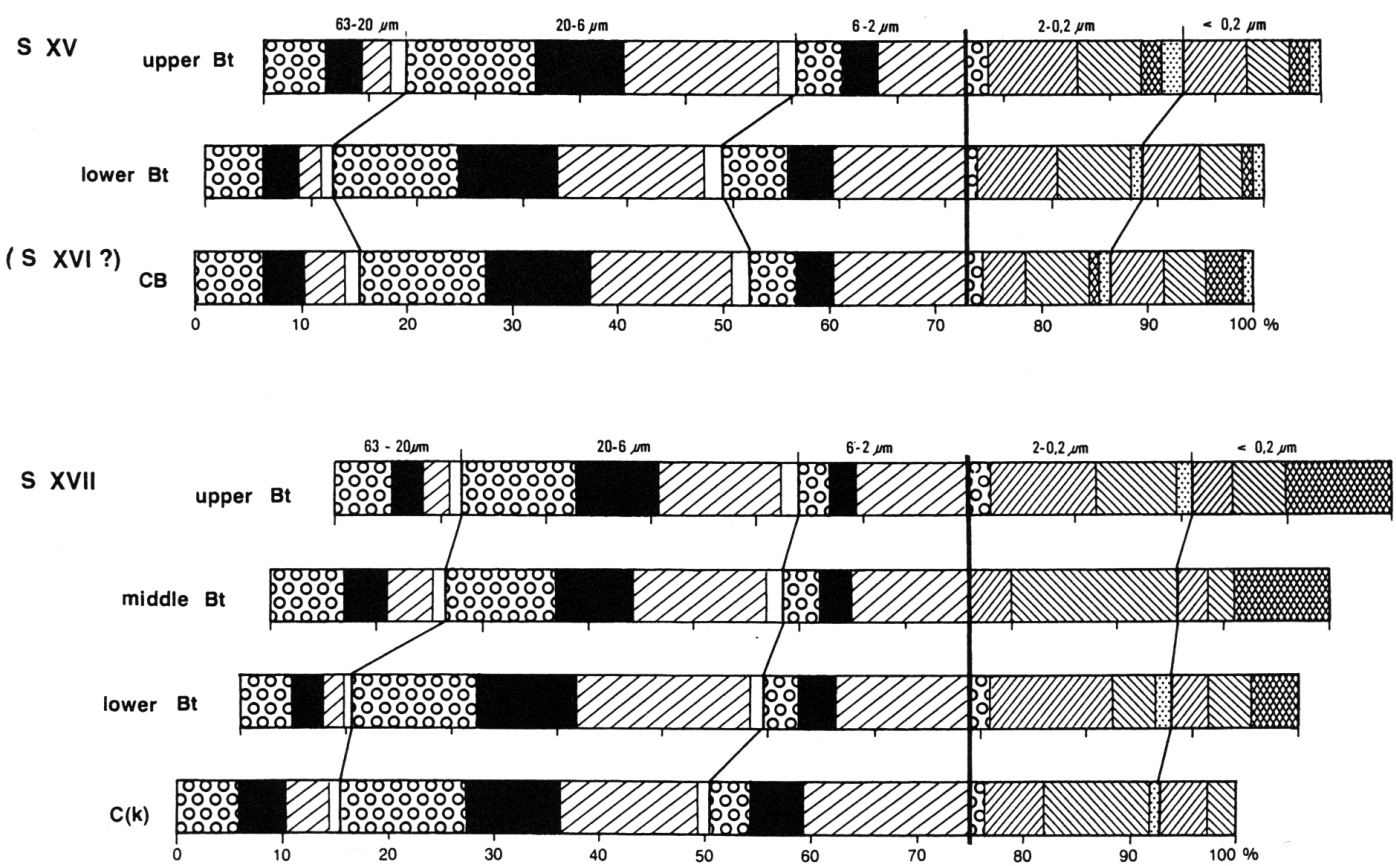

Figure 18 Mineralogical composition of the silt and clay subfractions of paleosols S XV (+ S XVI ?) and S XVII in the loess profile of Chashmanigar (Tadjik Depression). For legend see Figure 12.
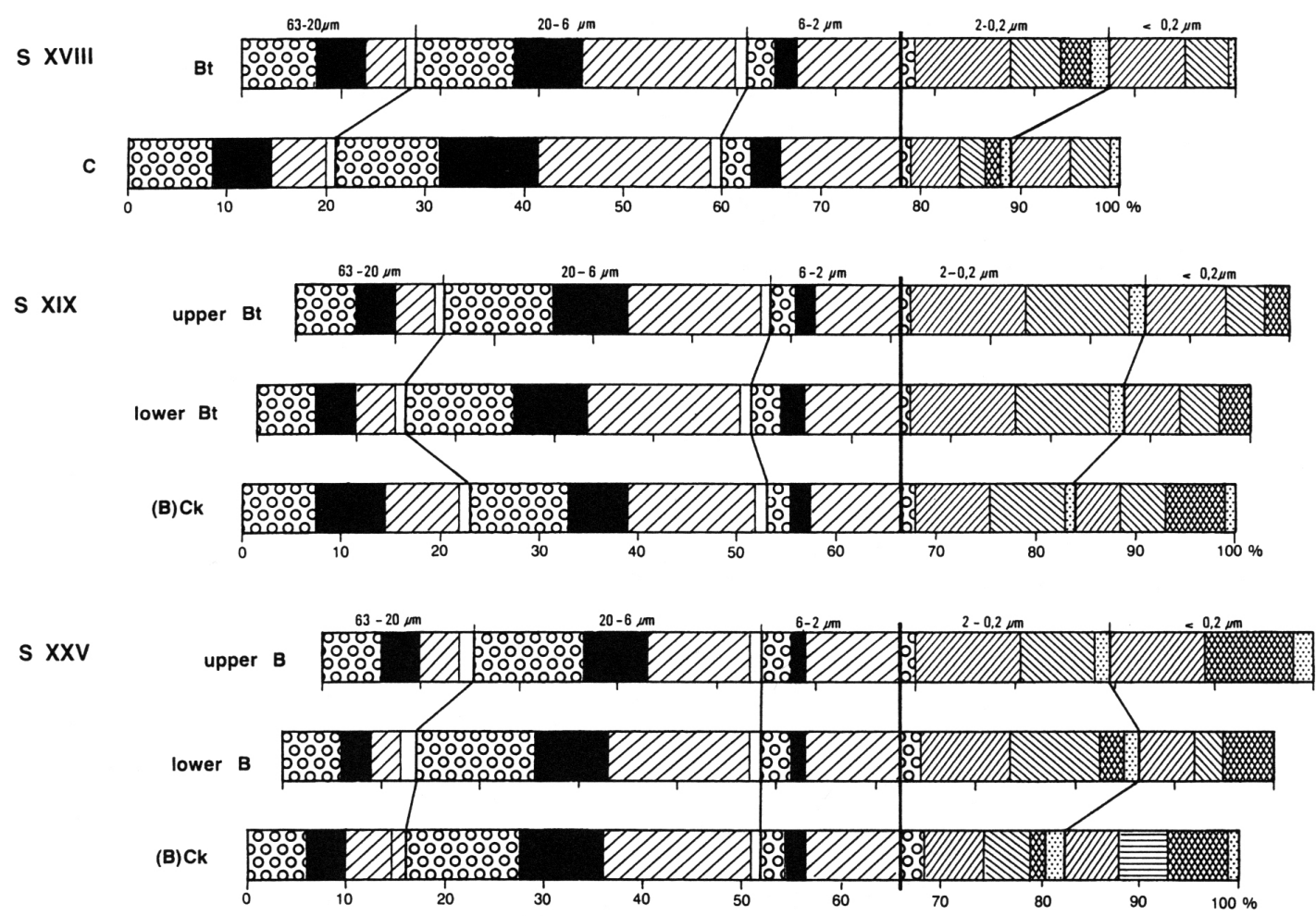

Figure 19 Mineralogical composition of the silt and clay subfractions of paleosols S XVIII, S XIX and S XXV in the loess profile of Chashmanigar (Tadjik Depression). For legend see Figure 12. 


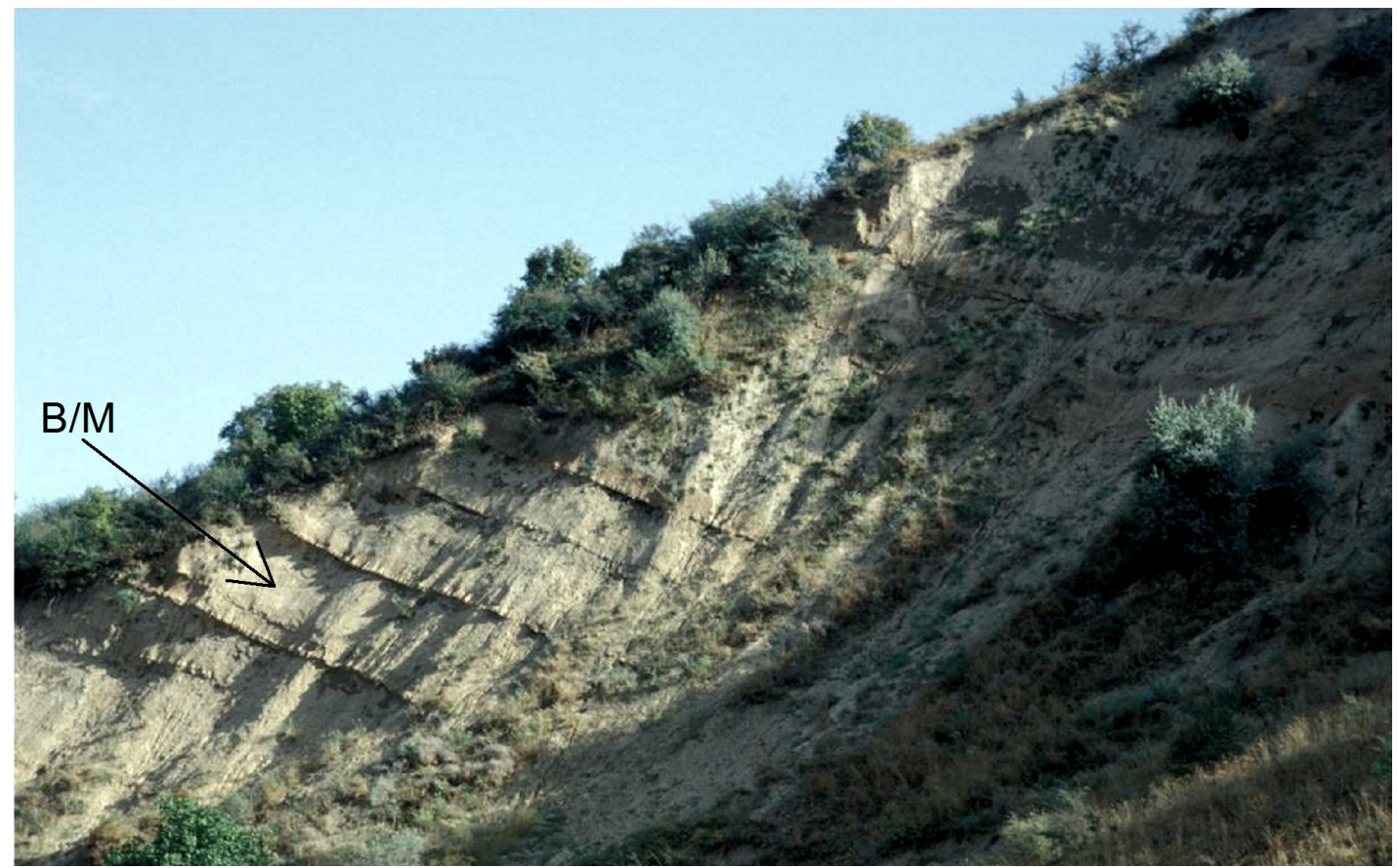

Figure 20 Lower part of Brunhes age loess-paleosol sequence of the section in Chashmanigar. - The autochtonous pedocomplexes $\mathrm{XI}$ to $\mathrm{V}$ are each underlain by $\mathrm{Ck}$ - loess kindl - horizons. The discordance between PK XI and PK X is located in both loess profiles in Chashmanigar and Karamaydan. Between PK X und PK IX the B/M boundary was located (Penkov and Gamov, 1980; Forster and Heller 1994).

investigations for a reliable time frame of the detailed LPS of the Matuyama chron in Chashmanigar (Figure 8) would be very helpful.

2. Most loesses generally are connected with a cold climate especially in the glacial stages. In the central Great Plains of the U.S.A., however, Holocene loess formation (Bignell Loess) is reported (e.g. Olson et al., 1997; Jacobs and Mason, 2004). It is underlain by the Brady Soil, which divided the late glacial Preoria Loess from Holocene Bignell Loess, which is up to $6 \mathrm{~m}$ thick e.g. in the Wauneta exposure in SW Nebraska. The Brady Soil developed between about 12.600 and 9.500 (cal. yr. BP; acc. to Johnson and Willey, 2000), at least during "a minimum of 2000 calendar years" (P. Jacobs, pers. comm.). Recently the age of the Brady Soil - regarded as a cumulative soil which grew upward in aggrading loess - was calculated between $15.040 \pm 900(\mathrm{OSL})$ and $10.310 \pm 90\left({ }^{14} \mathrm{C}\right)$ (Miao et al., 2016).

\section{Acknowledgements}

I gratefully acknowledge several financial supports of the German Research Foundation (DFG; grants Br303/18, 19, 20-1,2, 21-1,2 and 26-1,2) for field, micromorphological and laboratory work. Our sincere thanks are due to P. Kühn, F. Scarciglia and S. Sedov for valuable help in preparing the manuscript.

\section{References}

Barshad, I., 1967, Chemistry of Soil Development, in Bear, F.E. (ed.), Chemistry of the Soil: New York, U.S.A., Reinhold, 1-70 p.

Bassinot, F.V., Labeyrie, L.D., Vincent, E., Quidelleur, X., Shackleton, N.J., Lancelot, Y., 1994, The astronomical theory of climate and the age of Brunhes-Matuyama magnetic 
reversal: Earth and Planetary Science Letters, 126(1-3), 91-108.

Bibus, E., 1999, Loess-paleosol sequences in South Germany - Stratigraphy, Paleoclimate and Connections with River Terraces: Chinese Science Bulletin, 44(S1), 133-138.

Bibus, E., Rähle, W., Wedel, J., 2002, Profilaufbau, Molluskenführung und Parallelisierungsmöglichkeiten des Altwürmabschnitts im Lössprofil MainzWeisenau: E\&G Quaternary Science Journal, 51(1), 1-14.

Brewer, R., 1964, Fabric and Mineral Analysis of Soils: New York, U.S.A., John Wiley \& Sons, $470 \mathrm{p}$.

Bronger, A., 1966, Loesse, ihre Verbraunungszonen und fossilen Böden - ein Beitrag zur Gliederung des oberen Pleistozäns von Südbaden: Schriften des Geographisches, Institut der Universität Kiel, 25(2), 1-113.

Bronger, A., 1970, Zur Mikromorphogenese und zum Tonmineralsbestand quartärer Lössboden in Südbaden: Geoderma, 3(4), 281-320.

Bronger, A., 1974, Zur postpedogenen Veränderung bodenchemischer Kenndaten insbesondere von pedogenen Eisenoxiden in fossilen Lössböden, in Transactions of the 10th International Congress of Soil Science: Leningrad, USSR, 6(2), 429-441.

Bronger, A., 1976, Zur quartären Klimaund Landschaftsgeschichte des Karpatenbeckens auf paläopedologischer und bodengeographischer Grundlage: Kieler Geographische Schriften, 45, 1-268.

Bronger, A., 1991, Argillic horizons in modern loess soils in an ustic soil moisture regime: Comparative studies in forest-steppe and steppe areas from Eastern Europe and the United States: Advances in Soil Science, 15, 41-90.

Bronger, A., 2003a, Correlation of loesspaleosol sequences in East and Central Asia with SE Central Europe: towards a continental Quaternary pedostratigraphy and paleoclimatic history: Quaternary International, 106-107, 11-31.

Bronger, A., 2003b, Bodengeographie der Waldsteppen und Steppengebiete, in Blume, H., Stahr, K., Fischer, W., Guggenberger, G., Horn, R., Frede, H., Feliz-Henningsen (eds.), Handbuch der Bodenkunde: Berlin, Germany, Wiley, 1-60.

Bronger, A., Ensling, J., Gütlich, P., Spiering, H., 1983, Rubification of Terrae Rossae in Slovakia: A Mössbauer Effect Study: Clays and Clay Minerals, 31, 269-276.

Bronger, A., Ensling, J., Kalk, E., 1984, Mineralverwitterung, Tonmineralbildung und Rubefizierung in Terrae calcis der Slowakei: Ein Beitrag zum paläoklimatischen Aussagewert von Kalkstein-Rotlehmen in Mitteleuropa: Catena, 11(1), 115-132.

Bronger, A., Heinkele, T., 1989, Micromorphology and genesis of paleosols in the Luochuan loess section, China: pedostratigraphic and environmental implications: Geoderma, 45(2), 123-143.

Bronger, A., Heinkele, T., 1990, Mineralogical and Clay Mineralogical Aspects of Loess Research: Quaternary International, 7-8, $37-51$.

Bronger, A., Kalk, E., Schröder, D., 1976, Über Glimmer- und Feldspatverwitterung sowie Entstehung und Umwandlung von Tonmineralen in rezenten und fossilen Lössböden: Geoderma, 16(1), 21-54.

Bronger, A., Pant, R.K., Singhvi, A.K., 1987, Pleistocene climatic changes and landscape evolution in the Kashmir basin, India: paleopedologic and chronostratigraphic studies: Quaternary Research, 27(2), 167-181.

Bronger, A., Winter, R., Derevjanko, O. Aldag, S., 1995, Loess-Palaeosol-Sequences in Tadjikistan as a Palaeoclimatic Record of the Quaternary in Central Asia, in Derbyshire, E. (ed.), Wind Blown Sediments in the Quaternary Record: Chichester, U.K., Wiley, Quaternary Proceedings, 4, 69-81. 
Bronger, A., Winter, R., Sedov, S., 1998a, Weathering and clay mineral formation of two Holocene soils and of buried paleosols in Tadjikistan: towards a Quaternary paleoclimatic record in Central Asia: Catena, 34(1), 19-34.

Bronger, A., Winter , R, Heinkele, T., 1998b, Pleistocene climatic history of East and Central Asia based on paleopedological indicators of loess-paleosol sequences: Catena, 34, 1-17.

Bronger, A., Wichmann, P., Ensling, J., 2000, Over-estimation of efficiency of weathering in tropical "Red Soils": its importance for geoecological problems: Catena, 41(1-3), 181-197.

Buggle, B., Hambach, U., Glaser, B., Marković, S., Glaser, I., Zöller, L., 2008, Long-Term Paleoclimate Records in SE-Europe The Loess Paleosol Sequences Batajnica/ Stari Slankamen (Serbia) and Mircea Voda (Romania): Abhandlungen der Geologischen Bundesanstalt, 62, 15-19.

Buggle, B., Hambach, U., Müller, K., Zöller, L., Marković, S., Glaser, B., 2014, Iron mineralogical proxies and Quaternary climate change in SE-European loesspaleosol sequences: Catena, 117, 4-22.

Bullock, P., Fedoroff, N., Jongerius, A., Stoops, G., Tursina, T., Babel, U., 1985, Handbook for Soil Thin Section Description: Wolverhampton, U.K., Waine, 152 p.

Catt, J.A., 1989, Relict Properties in Soils of the Central and North-West European Temperate Region: Catena Supplement, 16, $41-58$.

Catt, J.A., 1990, Paleopedology Manual: Quaternary International, 6, 1-95.

Dodonov, A.E., 1986, Stratigraphy and paleogegraphy of loess in Middle Asia:
Annales Universitatis Mariae CurieSkllodowska Sectio B, Geographia, Geologia, Mineralogia et Petrographia, 41, 1-14.

Dodonov, A.E., 1991, Loess of Central Asia: GeoJournal, 24(2), 185-194.

Fink, J., 1964, Die Böden Niederösterreichs: Jahrbuch für Landeskunde von Niederösterreich, 36(2), 965-988.

Fink, J., Kukla, G., 1977, Pleistocene climates in Central Europe: at least 17 interglacials after the Olduvai event: Quaternary Research, 7(3), 363-371.

Forster, T., Heller , F ., 1994, Loess deposits from the Tajik depression (Central Asia): magnetic properties and paleoclimate: Earth and Planetary Science Letters, 128(3-4), 501-512.

Frechen, M., Preusser , F., 1996, Kombinierte Lumineszenz-Datierungen am Beispiel des Lössprofils Mainz-Weisenau: Frankfurter Geowissen-schaftliche Arbeiten Serie D, 20, 53-66.

Frechen, M., Horváth, E., Gábris, G., 1997, Geochronology of Middle and Upper Pleistocene Loess Sections in Hungary: Quaternary Research, 48(3), 291-312.

Frechen, M., Dodonov, A.E., 1998. Loess chronology of the Middle and Upper Pleistocene in Tadjikistan: Geologische Rundschau, 87(1), 2-20.

Heinkele, T., 1990, Bodengeographische und paleopedologische Untersuchungen in zentralen Lössplateau von China ein Beitrag zur quartären Klima- und Landschaftsgeschichte. Schriftenreihe Institut für Pflanzenernährung und Bodenkunde, Universität Kiel, 9, 1-120.

Heller, F., Liu, T.S., 1982, Magnetostratigraphical dating of loess deposits in China: Nature, 300, 431-433. 
Heller, F., Liu, T., 1984, Magnetism of Chinese loess deposits: Geophysical Journal of the Royal Astronomical Society, 77(1), 125-141.

Xiubin, H., Junliang, T., Keli, T., Jianzhong, S., Matthews, J.A., 2004, Bio-climatic imprints on a Holocene loess palaeosol from China: Journal of Asian Earth Sciences, 22(5), 455-464.

Hrasko, J., Linkes, V., Nemeček, J., Saly, R., Surina, B., 1973, Podna Mapa CSSR (Soil Map of Czechoslovakia), 1:500000: Bratislava, Czechoslovakia, Institute of Soil Science and Agrochemistry, 1 map.

IUSS Working Group WRB, 2014, World reference base for soil resources 2014: Rome, Italy, Food and Agriculture Organization, United Nations, World Soil Resources Reports, 106, $181 \mathrm{p}$.

Jacobs, P.M., Mason, J.A., 2004, Paleopedology of soils in thick Holocene loess, Nebraska, USA: Revista Mexicana de Ciencias Geologicas, 21(1), 54-70.

Johnson, W.C., Willey, K.L., 2000, Isotopic and rock magnetic expression of environmental change at the Pleistocene-Holocene transition in the central Great Plains: Quaternary International, 67(1), 89-106.

Kubiena, W.L., 1956, Zur Mikromorphologie, Systematik und Entwicklung der rezenten und fossilen Lössböden: E\&G Quaternary Science Journal, 7(1), 102-112.

Kubiena, W.L., 1959, Prinzipien und Methodik paläopedologischen Forschung im Dienste der Stratigraphie: Zeitschrift der Deutschen Geologischen Gesellschaft, 111, 643-652.

Kubiena, W.L., 1964, Zur Mikromorphologie und Mikromorphogenese der Lössböden Neuseelands, in Jongerius, A. (ed.), Soil Micromorphology: Amsterdam, The Netherlands, Elsevier, 219-235.

Kühn, P., Aguillar, J., Miedema, R., 2010, Textural Pedofeatures and Related Horizons, in Stoops, G., Marcelino, V., Meeds, S. (eds.), Interpretation of Micromorphological
Features of Soils and Regoliths: Amsterdam, The Netherlands, Elsevier, 217-250.

Kühn, P., Techmer, A., Weidenfeller, M., 2013, Lower to middle Weichselian pedogenesis and palaeoclimate in Central Europe using combined micromorphology and geochemistry: the loess-paleosol sequence of Alsheim (Mainz Basin, Germany): Quaternary Science Reviews, 75(1), 43-58.

Lisiecki, L.E., Raymo, M.E., 2005, A PliocenePleistocene stack of 57 globally distributed benthic $\partial^{18} \mathrm{O}$ records: Paleooceanography, 20, PA1003.

Lisiecki, L.E., Raymo, M.E., 2007, Plio-Pleistocene climate evolution: trends and transitions in glacial cycle dynamics: Quaternary Science Reviews, 26(1-2), 56-69.

Liu, T.S., 1985, Loess and the Enviroment: Beijing, China, Ocean Press, 251 p.

Maher, B.A., 1998, Magnetic properties of modern soils and Quaternary loessic paleosols: paleoclimatic implications: Palaeogeography, Palaeoclimatology, Palaeoecology, 137(1-2), 25-54.

Maisch, M., 1995, Alpine traverse, in Schirmer, W. (ed.), Quaternary Field Trips in Central Europe, XIV International Congress of the International Union for Quaternary Research: Berlin, Germany, International Union for Quaternary Research, 655-705.

Markovic, S.B., Hambach, U., Stevens, T., Kukla, G., Heller, F., McGoy, W., Oches, E., Buggle, B., Zöller, L., 201 1, The last million years recorded at the Stari Slankamen (Northern Serbia) loess-paleosoil sequence: revised chronostratigraphy and long-term environmental trends: Quaternary Science Reviews, 30, 1142-1154.

Miao, X.D., Wang, H., Hanson, P.R., Mason, J.A., Liu, X.D., 2016, A new method to constrain soil development time using both OSL and radiocarbon dating: Geoderma, 261, 93-100. 
Nishimura, S., Miao, J., Sasajima, S., 1984, Thermoluminescence dating of Paleosols in the Luochuan loess section, in Sasajima, S., Wang, Y. (eds.), The Recent Research of Loess in China: Kyoto, Japan, University and Northwest University, 69-78.

Olson, C.G., Nettleton, W.D., Porter, D.A., Brasher, B.R., 1997, Middle Holocene Aeolian activity on the High Plains of west-central Kansas: The Holocene, 7(3), 255-261.

Pécsi, M., Pevzner, M.A., 1974, Paleomagnetic measurements in the loess- sequences at Paks and Dunaföldvar, Hungary: Földrajzi Közlemények, 22(3), 215-224.

Pécsi, M., Richter., G., 1996, Löss: Herkunft, Gliederung, Landschaften: Zeitschrift für Geomorphologie, 98, 1-391.

Penkov, A.V., Gamov, L.M., 1980, Paleomagnetic datums in the Pliocene to Quaternary strata of southern Tajikistan: Leningrad, URRS, The Neogene-Quaternary Boundary (IGCP Project 41), Nauka, 189-194 p.

Rohdenburg, H., Meyer, B., 1966, Zur Feinstratigraphie und Paläopedologie des Jungpleistozäns nach Untersuchungen an südniedersächsischen und nordhessischen Lössprofilen: Mitteilungen Deutsche Bodenkundliche Gesellschaft, 5, 1-137.

Ruhe, R.V., Olson, G.G., 1980, Soil welding: Soil Science, 130(3), 132-139.

Schatz, A.-K., Scholten, T., Kühn, P., 2015, Paleoclimate and weathering on the Tokaj (Hungary) loess-paleosol sequence: Paleogeography, Paleoclimatology, Paleoecology, 426, 170-182.

Semmel, A., 1989, Paleopedology and geomorphology: examples from the western part of Central Europe, in Bronger., A., Catt, J. (eds.), Paleopedology - Nature and Application of Paleosols: Catena Supplement, 16, 143-162.

Semmel, A., 1999, Die paläopedologische Gliederung des älteren Würmlösses in
Mitteleuropa - Erörtert an Beispielen aus dem Rhein-Main-Gebiet: Zeitschrift für geologische Wissenschaften, 27(1-2), 121-133.

Sheldon, N.D., Tabor, N.J., 2009, Quantitative paleoenvironmental and paleoclimatic reconstructions using paleosols: EarthScience Reviews, 95(1-2), 1-52.

Singhvi, A.K., Bronger, A., Pant, R.K., Sauer, W., 1987, Thermoluminescence dating and its implications for the chronostratigraphy of loess-paleosol- sequences in the Kashmir Valley (India): Chemical Geology, Isotope Geoscience Section, 65(1), 45-56.

Singhvi, A.K., Bronger, A., Sauer, W., Pant, R.K., 1989, Thermoluminescence dating of loesspaleosol sequences in the Carpathian Basin (East-Central Europe): a suggestion for a revised chronology: Chemical Geology, Isotope Geoscience Section, 73(4), 307-317.

Smolíková, L., 1967, Polygenese der fossilen Lössböden der Tschechoslowakei im Lichte mikromorphologischer Untersuchungen: Geoderma, 1(3-4), 315-324.

Smolíková, L., 1971, Gesetzmäßigkeiten der Bodenentwicklung im Quartär: E\&B Quaternary Science Journal, 22(1), 156-177. Smolíková, L., 1990, Problematika paleopedologie. Regionalni paleopedologie, in Nemeček, J., Smolíková, L., Kutilek, M. (eds.), Pedologie a paleopedologie: Prague, Czech Republic, Academia, 381-505.

Smolíková, L., Havliček, P., Roetzel, R., 2010, Stratigraphy of Quaternary Fossil Soils along Highway A5 between Wolkersdorf and Schrick (Vienna Basin, Lower Austria): Abhandlungen der Geologischen Bundesanstalt, 65, 221-228.

Soil Survey Staff, 1999, Soil Taxonomy: Washington, D.C., United States Department of Agriculture, Natural Resources Conservation Service, Agriculture Handbook, 436, 869 p. 
Sprafke, T., 2016, Löss in Niederösterreich: Würzburg, Germany, Archiv quartärer Klima- und Landschaftsveränderungen, University Press, 1-247.

Stoops, G., 2003, Guidelines for analysis and description of soil and regolith thin sections: Madison, U.S.A., Soil Science Society of America, 1-184.

Wintle, A.G., 1987, Thermoluminescence dating of loess sections: a reappraisal, in Liu, T. S. (eds.), Aspects of Loess Research: Beijing, China, Ocean Press, 252-258.

Wintle, A.G., Packman, S.C., 1988, Thermoluminescence ages for three sections in Hungary: Quaternary Science Reviews, 7(3-4), 315-320.
Zachariae, G., 1964, Welche Bedeutung haben Enchytraeen im Waldboden, in Jongerius, A. (ed.), Soil Micromorphology: Amsterdam, The Netherlands, Elsevier, 57-86.

Zöller, L., 1995, Würm- und Rißlöß-Stratigraphie und Thermolumineszenz- Datierung in Süddeutschland und angrenzender Gebieten: Heidelberg, Germany, Faculty of Earth Sciences, Ruprecht-Karls University of Heidelberg, $\mathrm{PhD}$ Thesis, $224 \mathrm{p}$.

Zöller, L., 2000, Chronology of upper Pleistocene "red silts" in the Siwalik system and constraints for the timing of the upper palaeolithic in Nepal: Catena, 41(1-3), 229-235. 